\title{
ANNUAL SUMMARY OF PROGRAMS IN ENERGY SCIENCES
}

December 1977

DEPARTMENT OF ENERGY \& ENVIRONMENT

BROOKHAVEN NATIONAL LABORATORY ASSOCIATED UNIVERSITIES, INC.

UNDER CONTRACT NO. EY-76-C-02-0016 WITH THE

UNITED STATES DEPARTMENT OF ENERGY 


\section{DISCLAIMER}

This report was prepared as an account of work sponsored by an agency of the United States Government. Neither the United States Government nor any agency Thereof, nor any of their employees, makes any warranty, express or implied, or assumes any legal liability or responsibility for the accuracy, completeness, or usefulness of any information, apparatus, product, or process disclosed, or represents that its use would not infringe privately owned rights. Reference herein to any specific commercial product, process, or service by trade name, trademark, manufacturer, or otherwise does not necessarily constitute or imply its endorsement, recommendation, or favoring by the United States Government or any agency thereof. The views and opinions of authors expressed herein do not necessarily state or reflect those of the United States Government or any agency thereof. 


\section{DISCLAIMER}

Portions of this document may be illegible in electronic image products. Images are produced from the best available original document. 


\section{ANNUAL SUMMARY OF PROGRAMS IN ENERGY SCIENCES}

December 1977

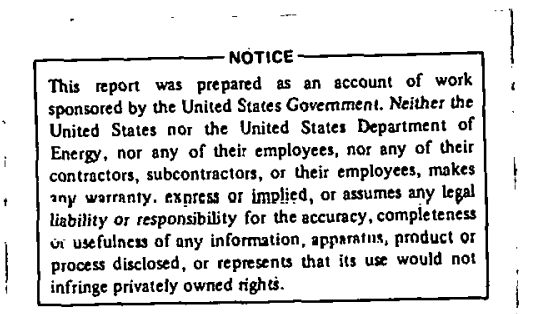

DEPARTMENT OF ENERGY AND ENVIRONMENT

\section{BROOKHAVEN NATIONAL LABORATORY \\ UPTON, NEW YORK 11973}


This report was prepared as an account of work sponsored by the United States Government. Neither the United States nor the United States Department of Energy (DUE), nor any of their employees, nor any of their contractors, subcontractors, or . their emplnyees, makes any warranty, express or implied, or assumes any legal liahility or responsibility for the accuracy, completeness or usefulness of any information, apparatus, product or process disclosed, or represents that its use would not infringe privately owned rights.

Printed in the United States of America $\Lambda$ vailablc from

National Technical Information Service U.S: Department of Commerce

5285 Port Royal Road

Springfield, VA 22161

Pricc: Printcd Copy $\$ 6.50$; Microfichc $\$ 3.00$ 
PREFACE

The principal function of this report is to present an inventory and brief overview of the research programs carried out in the Energy Sciences area of the Department of Energy and Environment. More complete and extensive descriptions of these programs exist in other documents, including the various publications cited herein.

In order to present the reader with something more than just a statement of past accomplishments, each program description includes a statement of activities planned for the coming year. Thus some sense of direction is indicatd for each program, and, taken in the aggregate, for the Energy Sciences area of the Department.

In compiling this report, M. Steinberg and M. Suenaga gave their full and prompt cooperation. Numerous secretaries lent their services to the typing and many other chores, but, lest an error of omission be committed, they are not here singly acknowledged.

D. J. Metz 
THIS PAGE

\section{WAS INTENTIONALLY LEFT BLANK}


TABLE OF CONTENTS

\section{$\underline{\text { Page }}$}

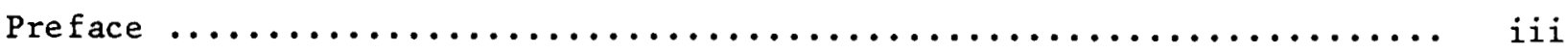

Introduction $\ldots \ldots \ldots \ldots \ldots \ldots \ldots \ldots \ldots \ldots \ldots \ldots \ldots \ldots \ldots \ldots \ldots \ldots \ldots \ldots$

Chemical Sciences Division $\ldots \ldots \ldots \ldots \ldots \ldots \ldots \ldots \ldots \ldots \ldots \ldots \ldots \ldots$

Porphyrin Chemistry $\ldots \ldots \ldots \ldots \ldots \ldots \ldots \ldots \ldots \ldots \ldots \ldots \ldots \ldots \ldots$

Investigations of the Chemistry of Energetic Compounds ........ 10

Kinetics and Mechanisms of Chemical Processes Related to the

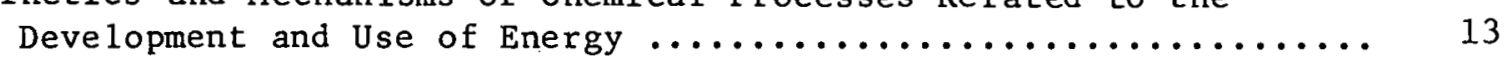

Combustion Studies on Alternate Fuels $\ldots \ldots \ldots \ldots \ldots \ldots \ldots \ldots \ldots$

Bioelectrochemistry and Electrochemistry $\ldots \ldots \ldots \ldots \ldots \ldots \ldots \ldots$

Molecular Structure of Porphyrins and Energy

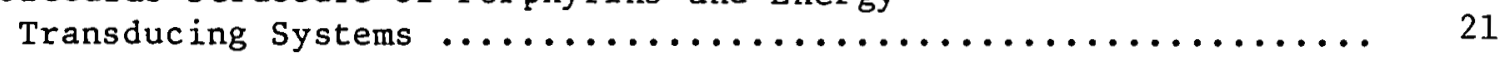

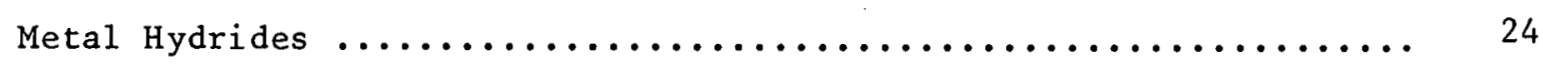

Chemistry and Physics of Coal Utilization $\ldots \ldots \ldots \ldots \ldots \ldots \ldots \ldots$

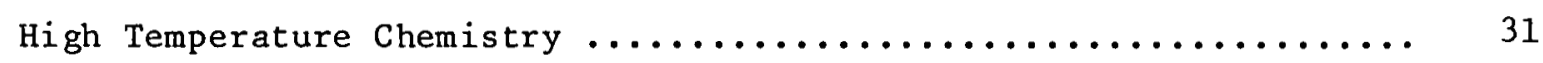

Cyclic Separations Process Research $\ldots \ldots \ldots \ldots \ldots \ldots \ldots \ldots \ldots \ldots$

Determining Fragile Molecules in the Environment ............ 37

Processing of Tritium in Solid Fusion Reactor Blankets ......... 39

Radiation Effects on Ion Exchange Materials ............... 41

High School Teachers' Institute on Energy $\ldots \ldots \ldots \ldots \ldots \ldots \ldots \ldots \ldots$

Programs Proposed for Initiation in FY $1979 \ldots \ldots \ldots \ldots \ldots \ldots \ldots$

Metallurgy and Materials Science Division .................. 46

Relationship Between Properties and Structures ............. 47

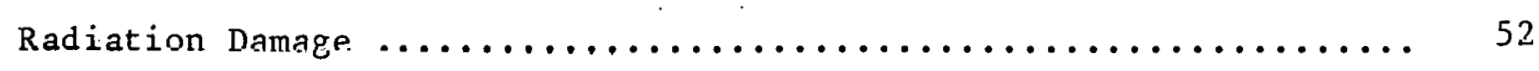

Physical Metallurgy of Metal Hydride Systems $\ldots \ldots \ldots \ldots \ldots \ldots \ldots$ 
Effects of Microstructures and Environment Upon

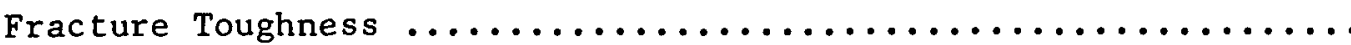

Superconducting Magnet Conductor Development Fabrication and Properties of Conductors for MFE Magnets ................ 59

Superconducting Power Transmission Lines ...................61

Intergranular Stress Corrosion of Iron and Nickel-Base Alloys ................................. 64

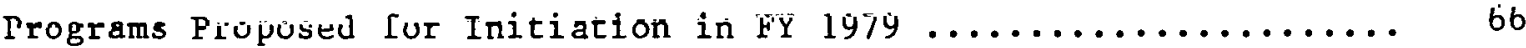

Process Sciences Division .................................67

Flash. Hydropyrolysis of Coal to Gaseous and Liquid

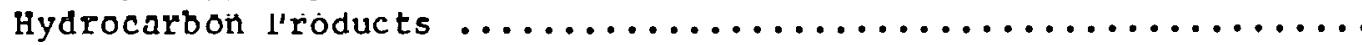

Regenerative Process for Desulfurization of High

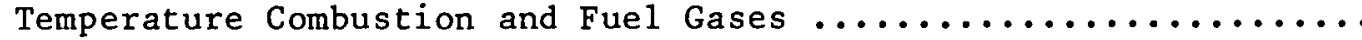

Geochemical Engineering, Alternate Materials of Construction for Geothermal Applications ................... 74

Geochemical Engineering, Cementing of Geothermal Wells ......... 77

Implementation of Concrete Polymer Research on Repair of Deteriorated Concrete ............................. 80

'Technology for Improvement of Wear Resistant Properties of Aggregates by Materials Impregnation ...................

Encapsulation of Phase Change Materials in Concrete

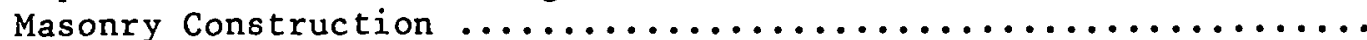

Development of a Glass Polymer Composite Sewer Pipe

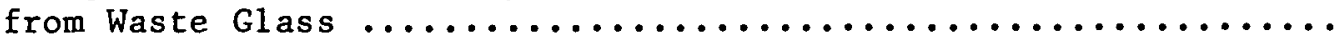

An Assessment of Environmental Control Technologies (ECT's) Involved on (1) The Flash Hydropyrolysis of Coal (FHP) and (2) Atmospheric Carbon Dioxide Control ................

Conservation in the Ethylene Polymer Tndustry; Polyketones and Polysulfones ............................94

Programs Proposed for Initiation in FY $1979 \ldots \ldots \ldots \ldots$ 


\section{INTRODUC.TION}

The Energy Sciences activities of the Department of Energy and Environment have as their ultimate objective the development of an understanding of the chemical, physical, material, and process phenomena basic to many. energy technologies encompassed by DOE's programs. In pursuit of this objective, activities are programmatically grouped within three Divisions:

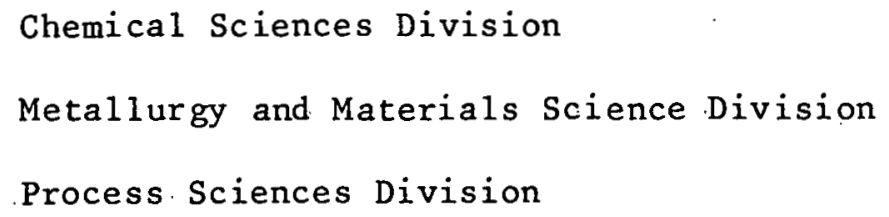

The Divisions are primarily administrative structures that provide greater cohesion and guidance to activities that naturally share common scientific approaches to specific problems. Each Division might be characterized by its individual main focus. Thus, in the Chemical Sciences Division the main focus is on basic chemistry; in the Metallurgy and Materials Science Division, on basic and applied materials research; and in the Process Sciences Division, on applied chemistry and chemical engineering.

The free flow of ideas and information across these dividing lines is fostered and occurs. There are a number of instances of complementary and interrelated programmatic interests not only among programs within a Division, but among the Divisions comprising the Energy Sciences area.

Within the Department, the Energy Sciences activities represent the basic research efforts, excluding environmental research, and much of the applied chemistry and chewical engineering work. It is expected that work performed in the Energy Sciences area will lead to the identification of ideas that are appropri- . ate for further development in either the Energy Technology area of the Depart- 
ment or by other Departments of the Laboratory. Several instances of such movement of ideas from the basic and applied areas to the development stage are: (1) basic research on the chemistry of metal hydrides leading to the application of metal hydride beds for hydrogen storage; (2) basic research on superconductivity and applied research on superconductor tape fabrication leading to participation in a joint program on ac superconducting power transmission; (3) applied research on polymer-impregnated concrete leading to a development program on the use of these materials for highway service and geothermal well applications.

The formal organizational relationships that exist among the Divisions of the Energy Sciences area, as well as those that exist among the other areas of the Department, are illustrated in the accompanying organizational chart.

The objective in assembling this report is to present an overview of all of the programs in the Energy Sciences area that were current in the calendar year 1977. The objective and scope of each program is described, as well as a summary of significant accomplishments for CY 1977. In addition, a brief statement. of the principal activities planned for the present year, $C Y$ 1978, is given. Finally, a list of publications in CY 1977 is provided, which enumerates all written or oral disclosures of work for which at least a BNL publication number has been issued.

A listing of programs that are being proposed for initiation in FY 1979 is given at the end of each section. 


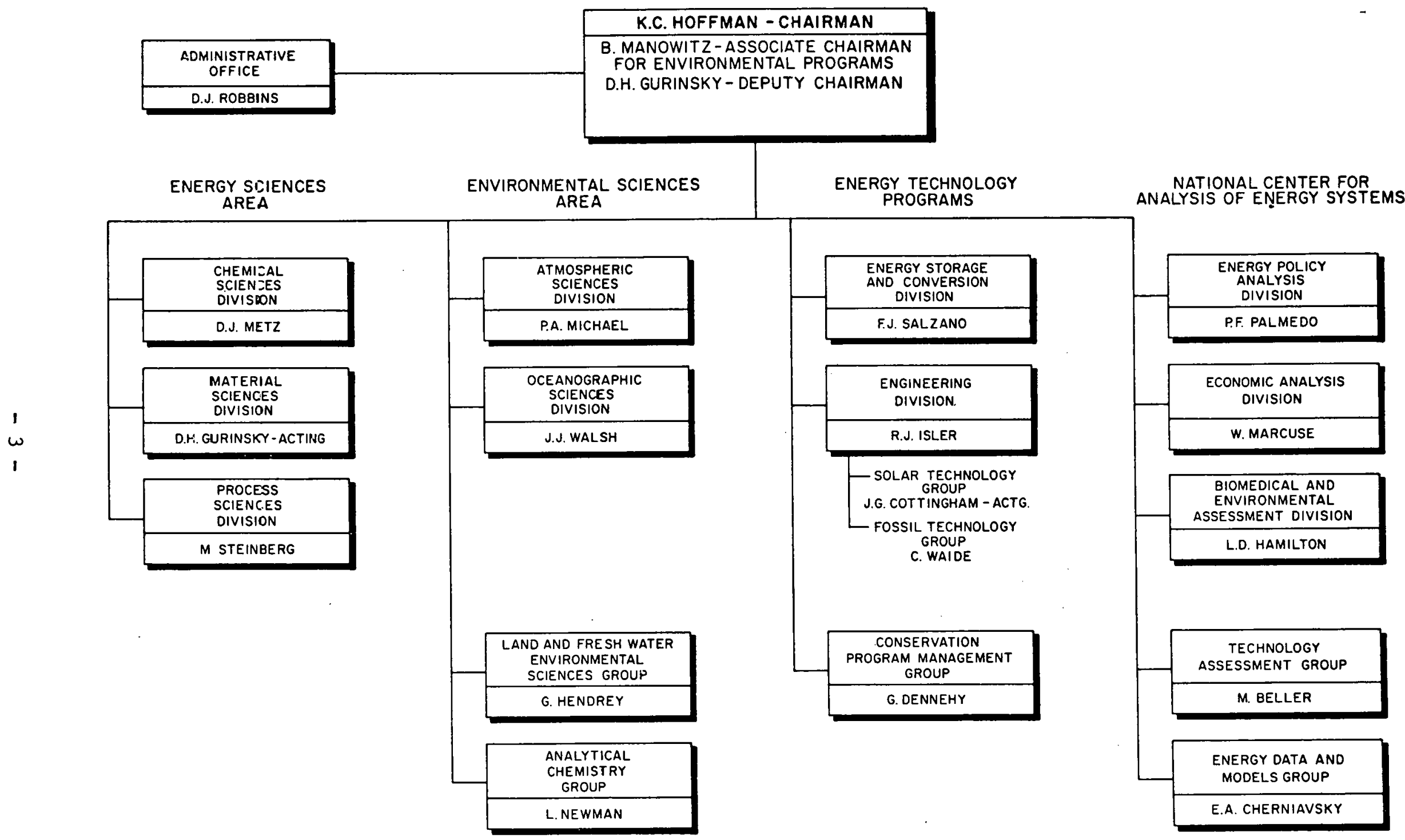




\section{CHEMICAL SCIENCES DIVISION}

\section{Donald J. Metz}

The programs of the Chemical Sciences Divison focus on understanding of chemical and physical phenomena basic to the energy technologies of DOE. The processes to which its present studies are relevant include: conversion of solar energy to chemical and/or electrical energy; coal gasification or liquefaction; hydrogen storage; combustion of liquid and gaseous fuels; fuel recovery and separation of hazardous wastes; nitrogen fixation; advanced battery development and magnetic fusion energy.

The programs represent a broad spectrum of both subject matter and investigative approach. All emphasize the systematic acquisition of high quality scientific data, directed toward one, or both, of the following goals:

1) developing basic understanding of phenomena and mechanisms, gaining new insights, and estab1ishing new concepts in chemical reactions pertinent to energy-related programs;

2) devcloping reliable techniques that are applicable to systems of concern in energy generation, conversion, or storage and in the control of the processes involved.

Following are brief descriptions of these programs. 
PORPHYRIN CHEMISTRY
FY 1977: $\$ 358,000$
Principal Investigator: J. Fajer
FY 1978: $\$ 395,000$
Sponsor: Basic Energy Sciences (DOE)

\section{Objective:}

The objective of this study is to understand the mechanisms of several biochemical catalytic processes, with particular emphasis on photosynthesis and phtotcatalysis. The ultimate goal is to provide information that will allow man to mimic, or improve upon, the naturally occurring processes and construct synthetic devices.

\section{Scope:}

Porphyrins are organometallic compounds that play indispensable.roles in biochemical energy conversion processes. The porphyrins function catalytically in these reactions, i.e., they are not consumed by the energy-producing process in which they participate. This work represents a multidisciplinary program that involves synthetic, structural, theoretical, and physical chemistry, and it encompasses (1) the electronic structure and chemical properties of porphyrins and their radicals; (2) the biological role of porphyrin ions in photosynthetic and metabolic reactions; and (3) applications of these catalytic reactions to energy-conversion systems such as solar energy production of electricity by photoexcitation of porphyrins deposited on solid interfaces or isolated in micelles, the production of hydrogen and/or oxygen in solution using porphyrins to mimic the photosynthetic cell and photodecompose water, and also to fix nitrogen photochemically via porphyrin derivatives. Step (3) would thus allow direct production of energy via the catalyzed photolysis of water to: form a fuel cell or for the storage of energy in the form of metal hydrides to be 
used as fuel (as a source of hydrogen) and in the form of nitrogen derivatives to be used as fertilizer.

The methods used to study these reactions, which involve oxidationreduction mechanisms, include techniques such as optical and photoacoustic spectroscopy, electron spin resonance (esr), nucle magnetic resonance ( $\mathrm{nmr}$ ), and electron nuclear double resonance (endor). The redox reactions are induced chemically, photochemically, and electrochemically, and the chemistry is guided by theoretical calculations used to predict the chemical properties of the model systems. These, in turn, are used to establish the role of the porphyrins in biuclienical calalysis.

Significant Accomplishments in 1977:

1. Additional evidence, in vivo, of the postulate that, on a picosecond time scale, bacterial pheophytin ( $B P h) \underline{b}$ acts as the prime electron acceptor in photosynthetic bacteria that contain complements of bacterial chlorophy11 (BC1) $\underline{b}$, and $\mathrm{BPh} \underline{\mathrm{b}}$ was obtained by studying the transient electron acceptor trapped in isolated reaction centers of Rhodopseudomonas viridis by electron spin resonance and election double resonance.

2. Significant progress was made in laying the groundwork for understanding the relationships between the two photosystems by which green plant photosynthesis proceeds: carbon dioxide flxation (photosystem I) and uxygen evolution (photosystem II).

3. Using a simply constructed ce11, containing films of porphyrins, chlorins, and bacteriochlorins deposited on one electrode, the trapping, transfer, and transduction of light into chemical energy was studied. It was found that, in the most favorable case observed, the energy efficiency for 
monochromatic 1 ight exhibited by magnesium porphyrin approached $2 \%$, at $\lambda=420$ $\mathrm{nm}$.

\section{Principal Activities Planned for 1978:}

1. Additional work on the relationships between photosystems I and II will be done. As part of the modeling studies of photosystem II, porphyrins and phthalocyanines will be investigaged as photo- and electrocatalysts in water decomposition or oxygen reduction by electrolysis.

2. Energy migration, charge transfer and sensitizing mechanisms, redox potentials, and reactivities of porphyrin excited states, induced by high power lasers in fluid and solid states will be studied.

3. Porphyrins and their radicals characterized to date will be tested for reaction with small molecules such as $\mathrm{CO}, \mathrm{SO}_{2}, \mathrm{SO}_{3}, \mathrm{O}_{3}$, NO, and $\mathrm{NO}_{2}$ for attack on the metal and porphyrin moiety as models of pollutant-induced damage.

4. The possibility of developing a nitrogen-fixing artificial system, based on photoreaction of porphyrins and an assumed model for the known multielectron reduction of sulfur and nitrogen compounds, will be investigated.

Publications in 1977:

Journal Articles

Fajer, J., Forman, A., Davis, M.S., Spaulding, L.D., Brune, D. C., and Felton, R. H. Anion radicals of bacteriochlorophyll a and bacterio-pheophytin a - a electron spin resonance and electron nuclear double resonance studies.. J. Am. Chem. Soc. 99, 4134 (1977).

Fajer, J., Davis, M.S., and Forman, A. Endor and Esr characteristics of bacteriopheophytin and bacteriochlorophyl1 anion radicals. Biophys. J. 17, 150a (1977). 
Fajer, J., Davis, M. S., Brune, D. C., Forman, A., and Thornber, J. P. Optical and paramagnetic identification of a primary electron acceptor of bacterial photosynthesis, J. Am. Chem. Soc., in press (BNL 23436).

Fajer, J., Davis, M. S., Brune, D. C., Thornber, J. P., and Forman, A. Photosynthesis at $1000 \mathrm{~nm}$. In Porphyrin Chemistry, Ann Arbor Science, in press, (BNL 23984) 1978.

Thornber, J. P., Dutton, P. L., Fajer; J., Forman, A., Holten, D., O1son, J. M., Parson, W. W., Prince, R. C., Tiede, D. M., and Windsor, M. W. Isolated photochemical reaction centers from bacteriochlorophyll b-containing organisms. In Photosynthesis 77: Proc. 4th Int. Congr. Photosynth., Ha11, D. 0., Coombs, J., and Goodwin, T. W., Editors, The Biochemical Society, London, in press, (BNL 24247).

\section{Oral Presentations}

Davis, M.S., Forman, A., Spaulding, L. D., and Fajer, J. Chlorin models of the chlorophylls of photosystems I and II. Presented at the 175th National Meeting of the Am. Chem. Soc., Anaheim, CA., Mar. 1977 (BNL 23634).

Hanson, L. K., Daviis, M. S., Fujita, I., and Fajer, J. Molecular orbital calculations of chlorophylls and chlorins. Presented at the Biophys. Soc. Meeting, Washington, D.C., Mar. 1977 (BNL -23636).

Fajer, J., Davis, M. S., Brune, D. C., Thornber, J. P., and Forman, A. Photosynthesis at $1000 \mathrm{~nm}$ : Radicals of bacteriochlorophyll b, bacteriopheophytin $\underline{b}$ and Rhodopseudomonas viridis. Invited paper presented at the Am. Chem. So., Newark, Delaware, Apr. 1977 (BNL 22154).

Thornber, J. P., Dutton, P. L., Fajer, J., Forman, A., 01son, J. M., and Prince, R. C. Isolated photochemical reaction centers trom bacterio-chlorophyll 
b-containing organims. Presented at the 4th Int. Congr. Photosynth., Reading, Engl and, Sept. 1977 (BNL 23306).

Fajer, J., Davis, M. S., Holten, D., Parson, W. W., Thornber, J. P., and Windsor, M. W. Kinetic and paramagnetic studies of primary processes in Rhodopseudomonas viridis. Presented at the 4th Int. Congr. Photosynth., Reading, Engl and, Sept. 1977 (BNL $\cdot 22781$ ). 
INVESTIAGTIONS OF THE CHEMISTRY OF ENERGETIC COMPOUNDS
FY 1977: $\$ 160,000$
Principal Investigator: M. Hillman
FY 1978: $\$ 170,000$
Sponsor: Básic Energy Sciences (DOE)

\section{Objective:}

The objective of this study is the preparation and characterization of classes of organic compounds that have the potential of possessing interesting properties as catalysts, photocatalysts, conductors, photoconductors, and, possibly, superconductors.

\section{Scope:}

The preparation, structure, and chemistry of energetic compounds are being investigated. Energetic compounds have the property that they may undergo certain types of reactions that ordinary compounds will not. Examples of these properties include such phenomena as the ability to catalyze other reactions and the ability to become electrical conductors under the influence of 1 ight. In the area of catalysis, this project is related to the possibility of fixation of nitrogen. In the area of conductivity, this project includes the possibilities of both photoconductivity and superconductivity in organic molecules. Heretofore, all work on organic superconductors has involved linear arrays of molecules. Present theory suggests that superconductivity in linear arrays is virtually impossible. This project is directed toward investigating the possibilities of preparing three-dimensional arrays that are potential conductors. These arrays would then have arrangements similar to those of the already known inorganic superconductors. Of particular interest are intensely colored derivatives of compounds al ready known to have some conductivity properties. Certain molecules incorporated in membranes can enhance the conductivity 
of the membranes. Ferrocene derivatives have been shown to do this. Photoconducting molecules incorporated in membranes may prove of practical interest in developing uses of solar energy.

\section{Significant Accomplishments in 1977:}

1. Having achieved the successful hydrogenation of $1,1^{\prime}, 2,2^{\prime}$-bis(trimethylene) ferrocene, progress has been made towards the goal of synthesizing a completely reduced bridged ferrocene that retains the iron atom trapped in the cage.

2. Starting with the three-trimethylene-bridged ferrocene $-1,1^{\prime}, 2,2^{\prime}, 4,4^{\prime}$ -tris(trimethylene) ferrocene - whose structure has been verified, it was shown that the attempt to introduce the fourth bridge, and subsequently the fifth bridge, causes rearrangement during the attempted formation of the fourth bridge, and the compounds formed are, respectively, a three-bridged compound with one homannular ring, and a three-bridged compound with two homannular rings. It had previously been reported that it was possible to insert the fourth bridge. The structure of the two compounds with homannular bridges was rigorously determined by $x$-ray diffraction.

3. Synthesis of two tetramethylene-bridged derivatives of ferrocene $-1,1^{\prime}$-tetramethylene ferrocene and 1,1',3,3'-bis (tetra-methylene) ferrocene has been accomplished. Mössbauer spectra show absence of ring tilt in these compounds.

Principal Activities P1 anned for 1978:

1. The preparation of multibridged tetramethylene ferrocenes will be pureued, hopefully, to the completely bridged compound.

2. Hydrogenation studies on the possible precursors of a caged free-iron atom compound will continue. 
Publications in 1977:

Journal Articles

Hillman, M. and Weiss, A. J. Szilard-Chalmers reactions of bridged derivatives of titanocene dichloride, zirconocene dichloride and hafnocene dichloride, J. Inorg. Nuc 1. Chem. 39, 1921 (1977).

Eisen, Y., Tserruyah, I., Eyal, Y., Fraenke1, A., and Hillman, M. Total fusion cross sections for ${ }^{18}, 17,160+27$ Al at energies near the coulomb barrier, Nucl. Phys., in press (BNL 22902).

Hillman, M., Gordon, B., Weiss, A. J., and Guzikowski, A. P., Bridged ferrocenes. I. J., Organomet: Chem., in press (BNL 23856).

Hillman, M. and Fujita, E., Bridged ferrocenes. I. The crystal and molecular structure of $1,1^{\prime}, 2,2^{\prime} 4,4^{\prime}-t r i s(t r i m e t h y l e n e)$ ferrocene, J. Organomet. Chem., in press (BNL 23857).

Hillman, M. and Fujita, E., Bridged ferrocenes. III. The crystal and molecular structure of $1,1^{\prime}, 2^{\prime} 2^{\prime}, 3,4,4^{\prime}, 5^{\prime}$-tektrakis(trimethylene) ferrocene, J. Organomet. Chem., in press (BNL 23855).

Spaulding, L. D., Williams, 1: .1. B., and Hillman, M., Bridged ferrocencs. IV. The crystal and molecular structure of $1,1^{\prime} 2,2^{\prime}, 3,3^{\prime}, 4,5,4^{\prime}, 5^{\prime}-$ pentakis (trimethylene) ferrocene, J. Organomet. Chem., in press (BNL 23861). BNL Reports

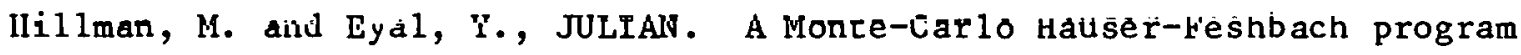
for evaporation from compound nuclei, Symposium on Neutron Cross-Sections from 10-40 MeV, Brookhaven National Laboratory, Upton, N.Y., May 3-5, 1977, Bhat, M. R. and Pearlstein, S., Editor, BNL-NCS-50681, July 1977. 
KINETICS AND MECHANISMS OF CHEMICAL PROCESSES RELATED TO THE

DEVELOPMENT AND USE OF ENERGY
FY 1977: $\$ 145,000$
Principal Investigator: J. W. Sutherland
FY 1978: $\$ 160,000$
Sponsor: Basic Energy Sciences (DOE)

\section{Objective:}

The objective of this study is to develop kinetic information, rates, and reaction mechanisms about specific chemical systems associated with the development and use of energy sources for which present data re inadequate or unavailable.

\section{Scope:}

The reactivity of sulfur dioxide and of transient intermediate nitrogen hydrogen compounds is being investigated. The photochemistry of selected molecules adsorbed on high surface area solids is also being studied, as well as the chemistry of transient intermediate nitrogen-hydrogen compounds. .

The results of the investigation, in addition to their intrinsic value to the general field of chemical kinetics, are available as quantitative input data for energy models designed to assess the relative impacts of using various energy sources. Flash photolytic and pulse radioly-tic techniques are used to characterize short-lived transient chemical species, while steady-state photolytic, steady-state radiolytic, and standard kinetic techniques are used to identify and measure yields of final products of a particular overall reaction. Information developed in this program is relevant to problems in sulfur chemistry associated with the development and use of geothermal energy sources and of fossil fuels, and pertinent to investigations into methods for nitrogen fixation and the chemistry of alternate fuels. 
Significant Accomplishments in 1977:

1. A mechanism to account for the vapor phase oxidation of $\mathrm{SO}_{2}$ - by flash photolysis - was formulated in terms of the initial photochemical reactions and the formation and decay of aerosols following the flash.

2. A mechanism was developed to explain the iron-catalyzed oxidation of $\mathrm{SO}_{2}$ dissolved in water, including the effects of iron concentration, $S$ (where $S$ $=\mathrm{SO}_{2}+\mathrm{HSO}_{3}^{-}+\mathrm{SO}_{3}^{-}$) concentration, $\mathrm{pH}$, temperature, and ionic strength.

Principal Activities P1anned for 1.978:

1. The chemical reactivity of transient nitrogen species produced by photolysis of hydrazine and substituted hydrazines will be otudicd.

2. The radiolytic decomposition of water adsorbed on hydrogen ionexchange zeolites will be investigated.

3. Depending on the success on the mechanism postulated for the iron catalyzed oxidation of aqueous sulfur dioxide, catalysis by other transition metals may be studied.

Publications in 1977 :

Journal Articles

Sutherland, J. W. Transient intermediate species in the oxidation of hydrazine. Genetic Engineering for Nitrogen Fixation, A. Hollaender, Editor, Plenum Press, 1977.

\section{Oral Presencations}

Clinco, $\Lambda$. and Sutherland, J. W. Oxidation of sulfur dioxide in acidic aqueous solution. Presented at 173rd A.C.S. Meeting, New Orleans, Mar. 1977 (BNL 22090). 
COMPUSTION STUDIES ON ALTERNATE FUELS
FY 1977: $\$ 207,000$
Principal Investigator: R. B. Klemm
FY 1978: $\$ 235,000$.
Sponsor: Basic Energy Sciencies (DOE)

\section{Objective:}

The objective of this study is to provide information on and an understanding of the combustion of alternative fuels (such as hydrocarbons, methanol, ethanol, hydrogen, etc.) in internal combustion engines. Of primary interest is the effects of combustor operating conditions and fuel parameters on combustion efficiency, product emissions, and the mechanisms of combustion.

\section{Scope:}

It has recently become necessary for the U.S. to consider the utilization of unconventional or alternative fuels such as solvent-refined coal and hydrogen, methanol, and synthetic gasoline derived from coal. In addressing some technical aspects of the alternative fuels question, such as combustion efficiency and pollutant emission rates, this program has two essential purposes: first, to investigate those alternative fuels that may be used to supplement or replace petroleum-derived fuels for operation in internal combustion engines and stationary combustion devices; and second, to study the combustion and pollutant formation processes that occur during the use of these fuels to clarify the fundamental principles involved. A two-phase program has been established that is designed to accomplish these objectives. In the first phase, a single-cylinder test engine (ASTM-CFR engine) and $\mathrm{flat-flame} \mathrm{burners} \mathrm{are} \mathrm{used} \mathrm{to} \mathrm{provide} \mathrm{realis-}$ tic test bases for measuring the effects of operating parameters, such as fuel type and air-fuel ratio, on the pressure, temperature, and concentration profiles for stable and transient species that exist during the combustion of 
various fuels. Because of the significant role that elementary chemical reactions may $\mathrm{pl}$ ay in determining observed combustion characteristics, the results of the first phase of this program, as well as those from other investigations, are used to define the potential importance of specific reactions that occur during the combustion process. In the second phase, the specific modes and rates of the indicated chemical reactions are determined in controlled and isolated experiments that eliminate the complexities of actual combustion devices. Combustion modeling studies are performed to consolidate the results of the laboratory research.

\section{Significant. Arr.nmplishments in 1977 :}

1. The Arrhenius parameters for the reactions

$$
\begin{aligned}
& \mathrm{H}+\mathrm{H}_{2} \mathrm{CO} \quad(264<\mathrm{T}<479 \mathrm{~K}) \\
& \mathrm{O}+\mathrm{H}_{2} \mathrm{CO} \quad(250<\mathrm{T}<498 \mathrm{~K})
\end{aligned}
$$

were determined.

2. A discharge flow-resonance fluorcocence ractor, to extend the upper temperature limit for rate data measurements, was constructed and tested.

3. A reliable, noninterfering exhaust gas-drying technique was developed and was demonstrated to be far superior to previnusly practiced techniques.

4. Applying this drying technique in the measurement of NO and $\mathrm{NO}_{2}$ emitted in the combustion of methanol and of iso-octane, it was found that ${ }^{N O}{ }_{x}$ emissions reported in previous, studies, in which $\mathrm{NO}_{2}$ was either not directly measured or lost through condensation or drying in the sampling system, are probably artificially low. 


\section{Principal Activities P1 anned for 1978:}

1. The fast flow reactor, constructed and tested in 1977 , will be fitted with a quartz flow tube to extend its useful range to $1300 \mathrm{~K}$, and measurement of the kinetic parameters of 0 -atom and $\mathrm{H}$-atom reactions with propane, butane, ethanol, formaldehyde, and acetaldehyde will be performed.

2. Installation of a dc dynamometer on the CFR engine will be completed and shakedown tests will be done.

3. An attempt will be made to determine the mechanism of $\mathrm{NO}_{2}$ formation in the combustion process. This will include careful measurements of NO and $\mathrm{NO}_{2}$ concentration profiles, NO to $\mathrm{NO}_{2}$ conversion, $\mathrm{NO}_{2}$ to $\mathrm{NO}$ conversion, and $\mathrm{NO}_{\mathrm{x}}$ losses in the entire sampling train; measurement of time-resolved combustion temperatures and exhaust system profiles to determine when and where $\mathrm{NO}_{2}$ formation is thermodynamically favored; and kinetic calculations to determine whether $\mathrm{NO}_{2}$ is formed by homogeneous or heterogeneous (wa11) reactions.

\section{Publications in 1977:}

\section{Oral Presentations}

$\mathrm{K} l \mathrm{emm}, \mathrm{R}$. B. Rate parameters for the reactions of formaldehyde with $\mathrm{H}-$ atoms and 0-atoms over the temperature range $250-470 \mathrm{~K}$. Presented at the Fa11 1977 Meeting - Eastern States Section - The Combustion Institute, Nov. 10-11, 1977, Hartford, CO. (BNL 23550).

Brateman, J. H. and Klemm, R. B. Single cylinder spark ignition engine study of $\mathrm{NO}$ and $\mathrm{NO}_{2}$ emissions for methanol, iso-octane and nitrogen doped methanol with emphasis on measurement technique. Presented at the Fall 1977 Meeting - Eastern States Section - The Combustion Institute, Nov. 10-11, 1977, Hartford, CO. (BNL 23549). 
Davis, R. E. and $\mathrm{Klemm}$, R. B. A determination of the branching ratio for the rate coefficient of the $0+\mathrm{CS}_{2}$ reaction using a diffuse crossed molecular beam apparatus (BNL 23172). 
BIOELECTROCHEMISTRY AND ELECTROCHEMISTRY
FY 1977: $\$ 108,000$
Principal Investigator: S. W. Feldberg
FY 1978: $\$ 150,000$
Sponsor: Basic Energy Sciences (DOE)

\section{Objective:}

The objective of this study is an understanding of the mechanism of conversion of light energy to chemical energy in biological systems, specifically that part of the process involving the transport of an electron across a membranewater interface and across the entire membrane. An understanding of this process will facilitate the successful construction of artificial photosynthetic devices.

\section{Scope:}

The major area of interest is the study of the kinetics and mechanisms of electron transfer between (photo) excited states of molecules (porphyrins, for example) bound to a bilayer lipid membrane (BLM) and acceptors or donors located either in the aqueous phases or within the BNL. A general objective of having reactants in two different phases, or immobilized within a phase, is the separation of the photogenerated products and the preclusion of the back reaction. Hopefully, the reaction products can perform some useful function (e.g., create a voltage which drives other ions across a membrane or modifies membrane transport properties; cause an electric current to flow through electrodes; lead to redox changes which produce $\mathrm{pH}$ changes or "energized" species (ATP)). A specific aim of these studies is the characterization of these processes: are these reactions, for example, governed by the same factors controlling homogeneous chemical reactions? The role of diffusion in bringing reactants to a photoactivated surface is being studied theoretically and experimentally. 
Diffusion effects provide additional information for quantitating surface density of excited states and excited state products.

Significant Accomplishments in 1977:

It was observed that the reaction between membrane-bound magnesium octaethylporphyrin, excited by light, and solution phase $\mathrm{O}_{2}$ leads to the transfer of an electron from the porphyrin to the $\mathrm{O}_{2}$ to form the superoxide ion:

$$
\mathrm{P}+\mathrm{P}^{*}+\mathrm{O}_{2}+\mathrm{P}^{+}+\mathrm{O}_{2}^{-}
$$

\section{Principal Activities Planned for 1978}

1. Attempts will be made to determine the surface density of $\mathrm{P}^{+}$(see reaction above) by studying the reaction between $\mathrm{P}^{+}$and solution phase $\mathrm{Fe}(\mathrm{CN})_{6}^{-4}$

2. The relative roles of singlet and triplet excited states of porphyrins in this process will be studied by using a series of other metal1npnrphyrins (other than magnesium) and also free-base porphyrins.

Publications in 1977:

Journal Articles

Feldberg, S. W. and Delgado, A. B. Inner voltage clamping: A method for studying interactions among hydrophobic ions in a lipid bilayer. Biophys., in press (BNL 22255R). 
MOLECULAR STRUCTURE OF PORPHYRINS AND ENERGY TRANDUCING SYSTEMS
FY 1977: $\$ 62,000$
Principal Investigator:
J. Fajer
L. D. Spaulding
FY 1978: $\$ 70,000$
Sponsor: Basic Energy Sciences (DOE)

Objective:

The objective of this study is to provide the structure-function and structure-reactivity correlations for compounds considered as potential energy transducers in photochemical or catalytic redox reactions.

\section{Scope:}

The compounds of principal interest include porphyrins, especially those containing multivalent transition metals; models of photosynthetic systems, such as oxidized, reduced, and neutral chlorins and bacteriochlorins; and dimeric and polymeric species in crystalline or monolayer arrays. The systems offer the stability and resolution necessary for detailed interpretation that are unavailable from the naturally occurring systems. Much more structural information is needed on currently studied model systems, as well as on new systems in preparation, to fully interpret electron spin resonance, nuclear magnetic resonance, resonance Raman spectroscopy, and theoretical calculations.

The techniques used include $x$-ray and neutron diffraction, extended $x$-ray absorption fine structure (EXAFS), photoacoustic spectroscopy, and singlecrystal microspectroscopy.

Significant Accomplishments in 1977:

1. The structure of $2,3,7,8$-tetrahydro- $\alpha, \beta, \gamma, \delta$-tetraphenylporphyrinatopyridine zine(II)-bezene solvate(I) was determined. The $x$-ray results confirm 
the postulated structure of isobacteriochlorins, which, to date, had only been inferred from analytic and spectroscopic measurements.

2. X-ray aca,tering from the metal (magnesium) was used to determine interlayer distances in multiple monolayers of magnesium porphyrins with variable length side chains. For magnesium dioctadecyl ester mesoporphyrin(IX), whose 18 carbon side chains approximate the 20 carbon phytols of chlorophylls, the metal-to-metal distance in successive layers was found to be $34.2(2) \mathrm{A}$.

3. The structure of the compound $1,1^{\prime}, 2,2^{\prime}, 3,3^{\prime}, 4,5^{\prime}, 5^{\prime}$ pentakis(trimethylene) ferrocene was determined. This compound was of interest to the Investigation of the Chemistry of Energetic Compounds Group, and provided them with definitive proof that the compound in question was not the suspected fivebridged trimethylene ferrocene.

\section{Principal Activities Planned for 1978:}

1. Work will be concentrated on growing and isolating crystals of monomers and dimers, as well as oxidized and reduced chlorins and bacteriochlorins, as models of the transients observed in the picosecond conversion of light into chemical energy.

2. To avoid the difficulties of growing single crystals of very reactive compounds large enough for $x$-ray or neutron diffraction, two additional structural probes will be introduced: (a) polarized single-crystal absorption microscopy, which requires only minicrystals or simply ordered tilms; and (b) EXAFS, which utilizes synchrotron radiation and works on powdered and even liquid samples . 
Publications in 1977:

Spaulding, L. D., Andrews, L. C., and Williams, G. J. B. Crystal and molecular structure of 2,3 -dihydro- $\alpha, \beta, \gamma, \delta$-tetraphenyloporphyrinatopyridinezinc(II)-benzene solvate, J. Am. Chem. Soc. 99, 6918 (1977).

Spaulding, L. D., Hillman, M., and Williams, G. J. B. Bridged

ferrocenes(IV). The crystal and molecular structure of $1,1^{\prime}, 2,2^{\prime}$, $3,3^{\prime} 4,5,4^{\prime}, 5^{\prime}$-pentakis (trimethylene) ferrocene. J. Organomet. Chem., in press (BNL 23861). 
METAL HYDRIDES
FY 1977: $\$ 259,000$
Principal Investigators: R. H. Wiswall
J. J. Reilly
FY 1978: $\$ 275,000$
Sponsor: Basic Energy Sciences (DOE)

\section{Objective:}

The objective of this study is an understanding of the basic chemistry and physics of metal-hydrogen systems, Metal hydrides comprioc a class of compuumls chat are ot intrinsic scientific interest; in addition, ccrtain metal hydrides already have potentially interesting appligationo in oueh energy-ielaled fields as hydrogen storage, isotope separation, and tritium scavenging.

\section{Scope:}

The storage of hydrogen in the form nf snlid metal hydridec promises to be important in the energy economy of the future. As a fuel, hydrogen has the advantages of being both nonpolluting and easily interconvertible with other forms of energy. The difficulties that its storage presents have been partially solved by the development of new alloy hydrides. Further improvemento will be fostered by an increased understanding of the basic chemistry and physics of metal-hydrogen systems. Such understanding, which is the long-range goal of this program, is sought chiefly through determination of pressuretemperature-composition relationships for selected metal-hydrogen systems, ralculation of thermodynamic properties derivable therefrom, and the determination of the crystal structures of metal hydrides. Associated with the latter goal is the devising of ways to prepare single crystals.

Hydrides also have potential value as components of processes for deuterium production or tritium scavenging. Here, too, there are required basic data on 
the equilibria and kinetics of gas-solid exchange reactions involving the pertinent isotopes, and the development of correlations between isotopic and other properties of alloy-hydrogen systems.

Significant Accomplishments in 1977:

1. An important difference was observed in the laws governing hydrogen absorption between pure metals and random alloys, on the one hand, and intermetallic compounds on the other. If sustained by further research, this general behavior should have important implications in explaining the relationship of hydride stability and structure.

2. A number of single-crystal metal hydrides were prepared for structural studies by BNL's Chemistry Department. Of particular significance, a singledomain single crystal of $\mathrm{TaD}_{0.77}(\sim 0.3 \mathrm{~g})$ was prepared.

3. It was observed that the magnetic susceptibility of FeTi is increased by several cycles of hydriding and dehydriding, and rapidly approaches a maximum.

Principal Activities Planned for 1978:

1. The relationship between thermodynamic properties and structure in Laves phase alloys will be investigated. As a class, these alloys exhibit interesting reactions with hydrogen. For example, $\mathrm{TaV}_{2}$, which can be prepared in either an ordered C-15 Laves phase or a random solid solution, is an excellent candidate with which to explore the generalization mentioned above; $\operatorname{TiCr}_{2}$ exhibits a remarkably low degree of hysteresis (between hydriding and

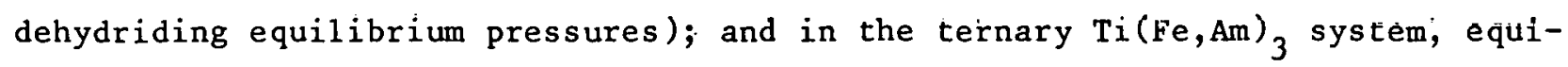
librium pressures depend on the Fe/metal ratio.

2. Magnetic susceptibility measurements will be performed on hydrides, such as europium-iridium and ytterbium-iridium, and dehydrided FeTi, in an 
attempt to gain deeper insight into structures of the hydrides and the effect of hydride-dehydride cycling on the alloys.

3. Attempts to prepare new metastable alloy structures, by hydriding and dehydriding, will be made.

4. The cooperative program on hydride structures, with the Chemistry Department, will focus on hydrides of the metals of Group V -- vanadium, niobium, and tantalum.

\section{Publications in 1977:}

\section{Journal Articles}

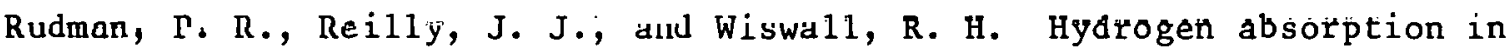
$\mathrm{Ti}_{3} \mathrm{Al}$. Ber. Bunsenges. Phys. Chem. 81 76, (1977)..

Reilly, J. J. Metal hydride. Yearbook of Science and Technology McGrawHil1, N.Y., 1977.

Reilly, J. J. Metal hydrides as hydrogen storage media and their applications, Chapter in Hydrogen: Trs Terhnolegy and Implicatione, Vol. IITransmission and Sţorage of Hydrogen, K. F. rnx and K., D. 'Williamson, Editorc, CRC Pléss, Dec. 1977.

Tanaka, J., Wiswall, R. H., and Reilly, J. J. Hydrogen isotope effects in titanium alloy hydrides. Inorg. Chem., in press (1978).

Rudman, P. R., Reilly, J. J., and Wiswall, R. H. The formation of metastable hydrides $\mathrm{Ti} .75^{\mathrm{Al}} \cdot 25^{\mathrm{H}} \mathrm{x}, \mathrm{x}<1.5$. J. Less-Common Met., in press (BNL 23296). Wiswall, R. H. Hydrogen storage in metals. Chapter in Hydrogen in Metals, Georg Alefeld, Editor, Springer-Verlag, N.Y., in press, (BNL 22324).

Lynch, J. F., Reilly, J. J., and Millot, F. The absorption of hydrogen by binary vanadium-chromium alloys. J. Phys. Chem. Solids, submitted for publication (BNL 23404). 


\section{BNL Reports}

Wiswa11, R. H., Reilly, J. J., Bloch, F., and Wirsing, E. Hydrogen isotope exchange in metal hydride columns. BNL 50755.

\section{Oral Presentations}

Reilly, J. J. and Johnson, J. R. The reactions of hydrogen with intermetallic compounds. Presented at 2nd Joint Conf. Chem. Inst. Canada and Am. Chem. Soc., Montreal, June 1977 (BNL 22135).

Lynch, J. F., Reilly, J. J., and Tanaka, J. Hydrogen absorption by titanium-molybdenum alloys. Presented at 2nd Joint Conf. Chem. Inst. Canada and Am. Chem. Soc., Montreal, June 1977 (BNL. 22123).

Tanaka, J., Reilly, J. J., and Lynch, J. F. Hydrogen isotope effect in solid solutions of $\mathrm{Ti}-\mathrm{Mo}$ as a function of alloy compostion. Presented at 2nd Joint Conf. Chem. Inst. Canada and Am. Chem. Soc., Montreal, June 1977 (BNL 22124).

Reilly, J. J. Synthesis and properties of useful metal hydrides. Proc. Int. Symp. Hydrides for Energy Storage, Geilo, Norway, August 1977 (BNL 23047). Reilly, J. J. Applications of metal hydrides. Proc. Int. Symp. Hydrides for Energy Storage, Geilo, Norway, August 1977 (BNL 23046). 
CHEMISTRY AND PHYSICS OF COAL UTILIZATION
FY 1977: $\$ 200,000$
Principal Investigators:
R. T. Yang
D. R. MacKenzie
FY 1978: $\$ 210,000$
Sponsor: Basic Energy Sciences (DOE)

\section{Objective:}

The objective of this study is to develop basic information, at the molecular level, of several physical and chemical processes important in the utilization of coal, in order that efficient and environmentally acceptable processes may be developed.

\section{Scope:}

Processes of interest include combustion, gasification, liquefaction, desulfurization, and carbonization, and work proceeds along three main lines of investigation: (1) high-temperature $\left(800^{\circ}\right.$ to $1600^{\circ} \mathrm{C}$ ) gas-carbonaceous material reactions; (2) mechanisms of hydrogenation; and (3) mechanically assisted hydrogenation (mechanochemistry), a phenomenon recently observed in the course of these studies.

'lhe high-temperature studies are directed toward understanding the nature of the heterogeneous process(es) occurring, including diffusion in porous media, the intrinsic chemical reactivity of coal, and the interplay between them.

Study of the mechanism of chemical hydrogenation of coal focuses on the use of model compounds to determine the most likely site(s) of attack on the coal structure, as well as the mechanism(s) underlying the role of hydrogen-donor solvents in coal hydrogenation processes.

The study of the mechanochemical hydrogenation of cnal, both neat and in hydrogen-donor solvents, attempts to understand the chemical and structural pa- 
rameters that may be important in utilizing mechanical energy to initiate the chemical reaction(s).

\section{Significant Accomplishments in 1977:}

1. Preliminary mathematical models for the gas-porous carbon system, containing both intrinsic chemical reaction rates and pure diffusion rates, were constructed.

2. In the vapor phase, between $120^{\circ}$ and $430^{\circ} \mathrm{C}$, it was shown that the sequence by which tetralin forms naphthalene involves the intermediate 1,2dihydronaphthane, and not 1,4-dihydronaphthalene. The kinetics of the individual steps were observed to be first order.

3. It was observed that grinding coal in the presence of hydrogen has the effect of enhancing the formation of asphaltenes.

Principal Activities P1anned for 1978:

1. Surface diffusion studies of chemisorbed oxygen on carbon will be done, utilizing the basal plane of a near-single crystal of pyrolitic graphite.

2. Studies of the mechanism(s) of both the liquid and vapor phase hydrogenation of coal by hydrogen donor solvents will be pursued, using model compounds and, when appropriate, isotopic labels.

3. A quantitative determination of the effect of mechanical grinding on coal hydrogenation will be made.

\section{Publications in 1977:}

\section{Journal Articles}

Yang, R. T. and Steinberg, M. A diffusion cell method fur studying hetergeneous kinetics in the chemical reaction/diffusion controlled region. Kinetics of $\mathrm{C}+\mathrm{CO}_{2}+2 \mathrm{CO}$ at $1200-1600^{\circ} \mathrm{C}$, Ind. Eng. Chem. Fundam. 16, 235 (1977). 
Yang, R. T. and Steinberg, M. The reactivity of coal chars with $\mathrm{CO}_{2}$ at $1100-1600^{\circ} \mathrm{C}$, Div. Fuel Chem. Preprints, ACS 22(1), 12 (1977).

Yang, R. T., Liu, R. T., and Steinberg, M. A transient technique for measuring diffusion coefficients in porous solids. Diffusion in carbonaceous materials. Ind. Eng. Chem. Fundam. 16, 486 (1977).

Sethi, D. S., Yang, R. T., and Steinberg, M. Conversion of non-coking coal into coking type with methane and with hydrogen. Fue1, in press (BNL 23061).

Yang, R. T. and Liu, R. T. Gaseous diffusion in carbon with particular reference to graphite. Ind. Eng. Chem. Proc. Des. Dev., in press (BNL 23333). 
HIGH TEMPERATURE CHEMISTRY
FY 1977: $\$ 161,000$
Principal Investigator: J. J. Egan
FY 1978: $\$ 175,000$
Sponsor: Basic Energy Sciences (DOE)

\section{Objective:}

The objective of this study is to develop an understanding of the thermodynamic and electrical transport properties of a range of materials (including ionic crystals, solid and molten salts, and alloys) that are relevant to energy storage and conversion.

\section{Scope:}

This program studies the thermodynamic and transport properties of substances at high temperatures and attempts to explain the results in terms of appropriate atomic models. Electrochemical methods are stressed since they yield very accurate results and also have possible direct application to batteries, fuel cells, and solar cells, when new methods are developed. The techniques of solid state electrochemistry are employed extensively and work is directed toward development of this relatively new field. The movement of electrons and electron holes in both ionic crystals and molten salts is being examined in view of its fundamental importance and its potential applications. These include such diverse phenomena as battery self-discharge, development of new electrolytes for thermodynamic studies, and improvements in efficiency of production of metals by molten salt electrolysis for energy conversion. Substances of interest in this program include alloys that are semiconductors in the liquid and solid state with applications to solar cells, solid and molten salt electrolytes with direct application to high energy batteries, and fuel cells as well as high temperature reactor fuels. 
Significant Accomplishments in 1977:

1. The thermodynamic properties of several liquid barium alloys - compound semiconductors - were determined electrochemica11y.

2. Electrochemical studies of dilute ternary alloys of calcium-magnesium with zinc, indium, and bismuth confirmed theoretical speculation that

nonideality in calcium-magnesium alloys with bismuth and other semimetals is due to changes in the Fermi energy of electrons at different alloy compositions.

3. The free energy of formation of calcium carbide was accurately determined.

4. Balumind, an important solld electrolyce, was shown to bécóme predominately an electronic conductor at $\sim 550^{\circ} \mathrm{C}$.

Principal Activities Planned for 1978:

1. The electrical conductivity of potassium-bismuth alloys will be determined as a direct function of chemical potential rather than composition, using a color center technique developed here.

2. Attempts will be made to measure the conductivity of compound semiconductors during the course of coulometric titration, aimed at achieving accurate control over the composition.

3. Measurements of the electronic conductivity of molten salts, including potassium chlordie, calcium chloride, lithium fluoride, and cryolite, will be performed.

Publications in 1977:

Journal Articles

Delcet, J., Heus, R. J., and Egan, J. J. Electronic conduction in solid $\mathrm{CaF}_{2}$ at high temperatures. J. Electrochem. Soc., in press (BNL 23383). 
Delcet, J. and Egan, J. J. Thermodynamics of liquid Ca-Zn alloys. Metal Trans. B, submitted for publication (BNL 23448).

Delcet, J. and Egan, J. J. Thermodynamics of liquid Ca-Ag and Ca-In

alloys. J. Less-Common Met., submitted for publication (BNL 23710).

Delcet, J. and Egan J. J. Thermodynamics of dilute ternary Ca alloys. Acta Metal1., submitted for publication (BNL 23809). 
CYCLIC SEPARATIONS PROCESS RESEARCH
FY 1977: $\$ 105,000$
Principal Investigators:
F. B. Hil1
Y. - W. Wong
FY 1978: $\$ 140,000$
Sponsor: Basic Energy Sciences (DOE)

\section{Objective:}

The objective of this study is the investigation of various cyclic separations processes, with a view toward their potential application to problems arising in energy technology.

\section{Scope:}

The cyclic processes of interest include heatless fractionation, parametric pumping, cycling zone adsorption, and various forms of preparative chromatography. Applications presently under study involve isotope separations of interest in nuclear reactor technology, specifically tritium removal and heavy water production. The program involves process design studies, experimental measurement of equilibrium and kinetic properties of selected fluid-solid separation systems, and measurement of characteristics of cyclic separation processing employing these systems.

Presently, hydrogen isotope separation via heatless fractionation is being studied. Protium-tritium separation is being investigated using the vanadium hydride system. Measurements are in progress on equilibrium pressure-hydride composition relationships and on the equilibrium tritium-protium separation factor for the particular batch of vanadium of commercial purity to be used in heatless fractionation experiments. Also in progress are experiments on the kinetics of isotope exchange in a flow system. Results of the equilibrium and kinetic measurements are used in constructing theoretical models of cyclic separa- 
tion process performance. Model predictions are compared to data obtained from a single process stage.

\section{Significant Accomplishments in 1977:}

1. The most important activity during the year was an experimental study of the rate processes involved in $\mathrm{HT}-\mathrm{H}_{2}$ exchange during $\mathrm{flow}$ through a vanadium hydride bed, including kinetic studies using a square-wave pulse of $\mathrm{HT}$ in $\mathrm{H}_{2}$ and an investigation of the performance characteristics of a single stage of a pressure cycling process (heatless adsorption).

2. In the analytical portion of the study, a model, including gas phase mass transfer external to a particle; gas-solid tritium-protium exchange, diffusion within the solid phase, and axial dispersion in the gas phase, was utilized to derive expressions for the moments of the HT concentration transients formed in the effluent stream of a hydride bed that result from introduction of a square-wave pulse of tritiated hydrogen gas into the entering $\mathrm{H}_{2}$ stream.

3. Analysis of the data obtained, in terms of the model so far developed, indicated that, since the velocity of a concentration front varies inappreciably with pressure but significantly with temperature, while the spreading of a front changes significantly with both pressure and temperature, a pressure cycling process would not be expected to work under this circumstance, but a temperature cycling processes might.

\section{Principal Activities Planned for 1978:}

1. Kinetic studies, using the elution chromatopgraphy technique previously employed, will be conducted at higher and lower temperatures than those previously employed, in preparation for exploring a temperature-cycling process.

2. Process work will concentrate on the study of the origin of so-called inverse separations in the pressure-cycling process examined last year. 
3. The equilibrium theory of pressure-cycling processes will be carried to completion. Work on the equilibrium theory of simple temperature-cycling processes will be developed.

4. Work will be started on the calculation of single separation stage performance in the presence of finite interphase exchange rates.

Publications in 1977:

None 
DETERMINING FRAGILE MOLECULES IN THE ENVIRONMENT
FY 1977: $\$ 100,000$
Principal Investogators:
L. Newman
R. Tanner
FY 1978: $\$ 110,000$
Sponsor: Basic Energy Sciences (DOE)

\section{Objective:}

The objective of this study is to devise and develop new analytical methods for the determination of potentially reactive substances in the environment.

\section{Scope:}

The specific approach adopted here is to develop analytical techniques based on the derivatization-chromatopgraphic separation-specific element detection scheme. Since many substances of interest may be reactive under analysis conditions, derivatization is used to convert the reactive or otherwise fragile substance to a derivative that can be separated from interferences and delivered quantitatively to a detector. Chromatographic techniques (gas, liquid, thin layer, ion exchange) are well-established methods for increasing analytical specificity by separating coderivatized substances and other interfering substances from the derivative of interest. Element-specific detectors, whose response is keyed to a single element or functional group, increase sensitivity by orders of magnitude for substances containing that element. This reduces the detector response for even gross amounts of potential interferences and simplifies the separation technology. The derivatization-chromatography-element specific detection principle is hroad and applicable to analysis of species of dynamically varying concentration in the aqueous environment (i.e., phosphate, nitrate, nitrite) as well as in the atmosphere (gaseous ammonia, nitric acid, sulfate in airborne particles). 


\section{Significant Accomplishments in 1977:}

1. The principal focus of this study was the development of a derivatization technique for traces of nitrate. Of those procedures investigated, derivatization with benzotrifluoride in the presence of trifluoromethylsulfonic acid appeared to be quantitative and complete.

2. Encouraging preliminary results were obtained with 2,3,5,6tetrafluoroanisole, which forms only one nitrobenzene derivative.

\section{Principal Activities Planned for 1978:}

1. A major effort will be made to develop the nitrate derivatization with both benzotrifluoride and 2,3,5,6-tetrafluoroanisole, and both sulfuric acid and trifluoromethylsulfonic acid nitration reagents.

2. Principal focus will be on developing a technique for fluorescent derivatization of ammonia and primary amines by reaction with phthaldehyde in the presence of 2-mercaptoethanol (reducing agent).

3. Feasibility studies will be initiated on the possibility of determining weak organic acids, by derivatizing them with an electron capture sensitive alcohol, such as heptafluoropropanol. Since, in environmental samples, these acids may be of natural origin (e.g., citric acid) or of anthropogenic origin (e.g., phenol and related compounds), both quantitative and qualitative analyses would be desirable.

Publications in 1977:

None 
PROCESSING OF TRITIUM IN SOLID FUSION REACTOR BLANKETS
FY 1977: $\$ 50,000$
Principal Investigator: R. H. Wiswall
FY 1978: $\$ 50,000$
Sponsor: Magnetic Fusion Energy (DOE)

\section{Objective:}

The objective of this study is to solve many of the chemical problems encountered in the development of continuous processes for recovering tritium from solid fusion reactor blanket materials.

\section{Scope:}

The study seeks to answer such questions as: Which is the best compound or alloy of lithium to use? How stable is it toward thermal decomposition and chemical reaction with other blanket materials? What method of preparation will give a product with good chemical properties, and suitable particle size? What are the best extraction conditions, in terms of composition of extracting gas, flow rate, temperature, and pressure? How is the performance affected by dose rate, total dose, and long exposure to the operating temperature? Will tritium be lost in adsorption on or diffusion into the various materials with which it can come in contact? How is tritium best recovered from a dilute gas stream? To answer these questions experimentally, rates of tritium extraction from small samples of neutron irradiated lithium compounds are measured under varying conditions of temperature, particle size, dose, etc. Changes in properties are followed by optical micrography and surface area measurements. The chemical stability of pure compounds and mixtures is followed by mass spectrometric analysis of gaseous products. 
Significant Accomplishments in 1977:

1. Effort was focused on measuring the physical characteristics and behavior toward tritium of four lithium compounds: $\mathrm{Li}_{2} \mathrm{O}, \mathrm{LiAlO}{ }_{2}, \mathrm{Li}{ }_{2} \mathrm{~S}$, and $\mathrm{Li}_{3} \mathrm{~N}$. In addition, some experiments were done with pellets containing $\mathrm{LiAlO}_{2}$ and nuclear grade graphite in the ratio of 1 to 10 (by weight). The following tentative conclusions were drawn:

a) At $600^{\circ} \mathrm{C}$, the estimated tritium diffusion coefficient in $\mathrm{Li}_{2} \mathrm{O}$ is approximately three orders of magnitude greater than in. LiAlO ${ }_{2}{ }^{\circ}$

b) At elevated temperatures, a slow chemical reaction appears to occur between carbon and $\operatorname{LiA} 10_{2}$.

c) $\mathrm{Li}_{2} \mathrm{Si}$ is classed with the ceramics $\mathrm{Li}_{2} \mathrm{O}$ and $\mathrm{LiAlO}_{2}$ as regards temperature at which useful tritium extraction can be achieved, rather than with LiAl and $\mathrm{Li}_{7} \mathrm{~Pb}_{2}$, which can be extracted at considerably lower temperatures.

2. Li ${ }_{3}^{\mathrm{N}}$ begins to decompose at $600{ }^{\circ} \mathrm{C}$, and is not considered a promising material for blanket purposes.

Principal Activities Planned for 1978:

1. The study of $\mathrm{LiAlO}_{2}$ systems will be completed.

2. The study of Li-Si systems will be completed.

3. The study of $\mathrm{Li}-\mathrm{Pb}$ systems will be completed.

Publications in 1977:

Wiswall, R. H. and Wirsing, E. The removal of tritium from fusion reactor blankets, BNL 50748, October 1977. 
RADIATION EFFECTS ON ION EXCHANGE MATERIALS

$\begin{array}{rrr}\text { FY 1977: } \$ 52,000 & \text { Principal Investigator: } \text { T. E. Gangwer } \\ \text { FY 1978: } \$ 5,000 & \text { Sponsor: } \begin{array}{l}\text { Nuclear Fuel Cycle and Production } \\ \text { (DOE) (subcontract from Oak Ridge }\end{array} \\ & \text { National Laboratory) }\end{array}$

\section{Objective:}

The objective of this study is an evaluation of the state of current knowledge on radiation damage to process chemicals and resins used in, as well as those with potential for use in, waste streams encountered in fuelreprocessing and refabrication plants.

Scope:

The study consists of a review of the literature on radiation degradation of solutes and resins and on the effects of secondary reactions initiated by radiation, with a view toward detailing degradation mechanisms, characterizing product buildup, identifying chemical intermediates, and evaluating potential hazards resulting from the intense radiation fields occurring in reprocessing streams.

\section{Significant Accomplishments in 1977:}

An extensive literature review and compilation of data on the radiation damage of ion exchange resins was completed. This included:
a) A review of the physical and chemical properties of ion exchangers;
b) Identification (or definition) of experimental parameters useful in characterizing radiation effects on synthetic ion exchange resins;
c) Presentation of experimental data and parameters in a format useful for intercomparing radiation effects;
d) Discussion of limitations and deficiencies in the literature; 
e) Outline of experimentation needed to achieve quantitative modeling. Principal Activities Planned for 1978:

Because of budgetary cut backs the program, which was scheduled through FY 1978, was terminated at the end of FY 1977. To complete the work on the ionexchange report, supplemental funds were extended into FY 1978. As a result of the program termination, that portion of the study on stream components other than resins could not be pursued. The program will be terminated with the completion of the formal report.

Publications in 1977:

NRNI. Reports

Gangwer, T. E. and Goldstein, M. Radiation Effects Chapter 9, ORNL/TM5888, June 1977.

Gangwer, T. E., Goldstein, M., and Pillay, K. K. S. Radiation Effects, Chapter 9, ORNL/TM 6056, October 1977. 
HIGH SCHOOL TEACHERS' INSTITUTE OF ENERGY
FY 1977: $\$ 15,000$
Principal Investigator: D. J. Metz
FY 1978: $\$ 15,000$
Sponsor: National Science Foundation

\section{Objective:}

The objectives of this activity are, in general, to intensify and expand the level of interaction between the local secondary science faculities and the scientific activities and expertise of the Laboratory, and, in particular, to help these high school teachers improve their abilities to teach and to discuss the various facets of our "energy crisis" with their students, colleagues, and communities at 1 arge.

\section{Scope:}

The Institute is available to teachers of science and mathematics (Grades 9 through 12) in the counties of Nassau and Suffolk, New York. The program consists of thirty evening sessions, each of three hours' duration, during the academic year. The Institute comprises two parallel, complementary activities: (1) lectures delivered by Laboratory staff members, and (2) workshop activities, guided by assigned advisors, who are also Laboratory staff members.

The thirty sessinns are subdivided into three time segments, as follows Segment I - Discussion of Basic Energy Concepts - 8 sessions Segment II - In-depth Study of Various Technologies and Conservation Measures - 12 sessions

Segment III- Comparative Analysis of Technologies - 10 sessions

Each participant is required to

1. make an oral presentation,

2. write a report, 
3. develop an individual project.

Significant Accomplishments in 1977:

1. The Institute, started in September 1976 under ERDA sponsorship, concluded in May 1977, with 30 participants, out of an original complement of approximately 40 , completing all the requirements.

2. The program was offered again, starting in September 1977, under National Science Foundation sponsorship. The initial enrollment was approximately 37 , and had decreased to 28 by the end of the calendar year.

Principal Activities P1anned for 1978:

1. The Institute, slalled in Seprember 1y/1, will end in May 1978, with a total of 28 participants anticipated to fulfill all the requirements.

2. If the program is funded again by NSF, another offering of the Institute will be made, starting September 1978.

Publications in 1977:

No publication for general distribution results from this program. However, the written reports of the participants are printed, bound, and distribuled to the partcipants and statt members involved. 
Programs Proposed for Initiation in FY 1979.

In addition to the programs sumnarized above, the Chemical Sciences Division has proposed to undertake several new programs in FY 1979. These are listed by title below:

Trace Element Analysis Using Synchrotron Radiation

Rotating Fluidized Bed Combustor

Aqueous Liquid Phase Methanation Catalysis

Fundamental Gas-Phase Particulate Processes 


\section{METALLURGY AND MATERIALS SCIENCE DIVISION}

David H. Gurinsky (Acting)

Presently, the major effort of this division is the investigation of superconducting properties of A-15 compounds with high-critical temperature and critical temperature and critical-current superconductors and the relationship of these properties to fabrication techniques, metallurgical treatments, nonhydrostatic stresses, and irradiation with protons, neutrons, and electrons. The applications of these materials to power transmission cables and high-field magnets are studied. New programs investigating materials problems in other energy-related technologies, such as metallurgical problems in metal hydrides, high temperature fracture failures and hydrogen embrittlements of structural materials, and amorphous semiconductors for solar energy applications were started. New techniques such as energy-dispersive $\mathbf{x}$-ray compositional analysis with a transmission electron microscope, smal1-angle neutron scattering, and extended $x$-ray absorption fine structures with synchrotron radiation will be employed as programs require these new techniques. 


\section{RELATIONSHIP BETWEEN PROPERTIES AND STRUCTURES}

FY 1977: $\$ 820,000$

FY 1978: $\$ 650,000$
Principal Investigators: R. Caton, D. DewHughes, 0. Kammerer, K. Lee, C. Pande, M. Suenaga, D. O. Welch.

\section{Objective:}

The objective of this program is to perform basic studies on the relationship of defects to macroscopic properties of superconducting and structural materials.

\section{Scope:}

This program covers basic studies of the relationship of defects to macroscopic properties. The research includes fundamental studies of high $\mathrm{T}_{c}$ materials; effects of nonhydrostatic strain on superconducting properties ( $T_{c}, J_{c}$, and $\mathrm{H}_{\mathrm{c} 2}$ ) of A-15 superconducting compounds; new fabrication processes of multifilamentary conductors with high critical temperature and high critical magnetic field superconductors other than $\mathrm{Nb}_{3} \mathrm{Sn}$ and $\mathrm{V}_{3} \mathrm{Ga}$; studies of microscopic damages in A-15 superconductors due to neutron as well as proton irradiation. Fundamental aspects of hydrogen embrittlement are also under study, as is the effect of dislocation substructure on flow stress and susceptibility to hydrogen embrittlement.

\section{Significant Accomplishments in 1977:}

1. Effects of irradiation-induced and compositional disorder on superconducting transition temperature of A-15 compounds have been elucidated.

2. The nature of the neutron-irradiation-induced defects in $\mathrm{Nb}_{3} \mathrm{Sn}$ was determined using transmission electron microscopy and electronic specific heat measurements. 


\section{Principal Activities P1anned for 1978:}

1. Effects of uniaxial stress on superconducting transition temperature of A-15 compounds will be investigated and be related to the influence of tensile stress on superconducting properties of composite conductors.

2. Hydrogen embrittlement of cold-worked $\mathrm{Ni}$ and $\mathrm{Fe}$ and $\mathrm{Fe}$ whiskers will be studied.

Publications in 1977:

Journal Articles

Dew-Hughes, D. Superconducting materials for large scale applications. Adv. Cryog. Eng. 22, 316 (1977).

Dew-Hughes, D. Effect of third element additions on the properties of bronze-processed $\mathrm{Nb}_{3} \mathrm{Sn}$. IEEE Trans. Magn. MAG-13, 651 (1977).

Luhman, T. S. and Suenaga, M. The influence of thermally induced matrix stresses on the superconducting properties of $\mathrm{Nb}_{3} \mathrm{Sn}$ wire. IEEE Trans. Magn., MAG-13, 800 (1977).

Pande, C. S. Effect of Nuclear irradiation on the superconducting transition temperatures of A-15 materials. Solid State Commun. 24, 241 (1977).

Welch, D. O. and Dienes, G. J. Phenomenological and microscopic models of sublattice disorder in ionic crystals-I. Phenomenological models. J. Phys. Chem. Solids $\underline{38}, 311$ (1977).

Dienes, G. J., Welch, D. O., and Platov, Yu. M. Radiation damage production in stage II; temperature and impurity effects. Radiation Eff. 33,59 (1977).

Viswanathan, R., Lawson, A. C., and Pande, C. S. Low temperature heat capacity of $\mathrm{LaRu}_{2}$ by ac technique. J. Phys. Chem. Solids 37, 341 (1977). 
Sweedler, A. R., Moehlecke, S., Jones, R. H., Viswanathan, R., and Johnston, D. C. Superconductivity of neutron irradiated Mo ${ }_{3}$ s: Solid State Commun. 21, 1007 (1977).

Viswanathan, R. and Ho, J. C. Heat capacity anomalies associated with structural transfer in $\beta-W$ and perovskite compounds. Ferroelectrics 17, 339 (1977).

Dew-Hughes, D. Phase diagram information for processing of superconductors. Proceedings of Workshop on Phase Diagrams in Metallurgy and Ceramics, Gaithersburg, Jan. 1977 in press (BNL22435).

Dew-Hughes, D. Solid state (bronze process) $V_{3}$ Ga from V-Al alloy core. J. Appl. Phys., in press (BNL 22855).

Dew-Hughes, D., Moehlecke, S., and Welch, D. Recovery of $\mathrm{T}_{c}$ by annealing of irradiated A-15 compounds. J. Nuc. Materials, in press (BNL 22925).

Dew-Hughes, D. and Suenaga, M. Critical current densities of bronze processed $\mathrm{Nb}_{3}\left(\mathrm{Sn}_{1-\mathrm{x}} \mathrm{Ga}_{\mathrm{x}}\right)$ wires up to 23.5 tesla. J. Appl. Phys., in press (BNL 22854R).

Viswanathan, R., Caton, R. and Pande, C. S. Superconductivity in irradiated A-15 compounds at low fluences 1 . Neutron-irradiated $\mathrm{V}_{3} \mathrm{Si}$. Jour. of Low Temp. Phys. in press (BNL 23127).

Pande, C. S. A mechanism for the degradation of superconducting transition temperatures in A-15 compounds on neutron irradiation. Jour. of Nuc. Materials in press (BNL 22708).

Welch, D. 0. and Lynn, K. G. An approximate method for calculating the lifetime of positrons trapped by lattice defects. J. Nucl. Macer., in press (BNL 21937). 
Welch, D. O., Lazareth, O. W., Dienes, G. J., and Hatcher, R.D. Clusters of alkali halide molecules. J. Chem. Phys., in press (BNL 23386).

Welch, D. 0., Paskin, A., and Dienes, G. J. A molecular dynamical study of the equation of state of solids at high temperature and pressure. J. Phys. Chem. Solids in press (BNL 23334).

Moehlecke, S., Cox, D. E., and Sweedler, A. R. The effects of composition and order on the A-15 phase of Nb-Pt. Solid State Commun., in press (BNL 22362).

Sweedler, A. R., Cox, D. E., and Moehlecke, S. Neutron irradiation of superconducting compounds. J. Nucl. Mater., in press (BNL 23299).

Luhman, T. S. and Dew-Hughes, D. Superconducting wires of $\mathrm{PbMo}_{5.1} \mathrm{~S}_{6}$ by a powder technique. Appl. Phys. Letters, submitted for publication (BNL 23043).

Dew-Hughes, D. Stress limitations on superconducting magnet performance. Cryogenics, submitted for publication (BNL 22941R).

Dew-Hughes, D., and Luhman, T. S. The thermonynamies of A-15 compound formation by diffusion from ternary bronzes. J. Mater. Sci., submitted for publication (BNL 23397).

Varmazis, C., Viswanathan, R., and Caton, R. A technique for bonding Au and Ag metals on sapphire. Rev. of Sci. Instrum. submitted for publication (BNL 23572).

Viswanathan, R. and Caton, R. Effect of neutron irradiation on single crystal $\mathrm{V}_{3} \mathrm{Si}$ heat capacity and resistivity. Phys. Rev. submitted for publication (BNL 23725).

Caton, R. and Sweedler, A. R. The dependence of the superconducting transition temperalure on silicon concentration in the NbAlsi ternary system. J. Less-Common Met. submitted for publication (BNL 23790). 


\section{Oral Presentations}

Caton, R. and Viswanathan, R. Electrical resistivity of single crystal $\mathrm{V}_{3} \mathrm{Si}$. Presented at APS Spring Meeting, San Diego, Mar. 1977 (BNL 22212).

Viswanathan, $R$. and Caton, $R$. Heat capacity of neutron irradiated $V_{3} S i$ single crystal. Presented at APS Spring Meeting, San Diego, Mar. 1977 (BNL 22199).

Caton, R. and Sweedler, A. The dependence of the superconducting transition temperature on silicon concentration in the Nb-Al-Si ternary system. Presented at APS Spring Meeting, San Diego, Mar. 1977, (BNL 22213).

Dew-Hughes, D. and Suenaga, M. Critical current densities of bronze processed $\mathrm{Nb}\left(\mathrm{Sn}_{1-\mathrm{x}} \mathrm{Ga}{ }_{\mathrm{x}}\right)$ wires up to $23.5 \mathrm{~T}$. Presented at AIME Fall Meeting, Chicago, Oct. 1977 (BNL 22707).

Dew-Hughes, D. Solid State (bronze process) $\mathrm{V}_{3}$ Ga from a V-Al alloy core. Presented at AIME Fal1 Meeting, Chicago, Oct. 1977 (BNL 22706).

Caton, R. and Viswanathan, R. Effect of neutron irradiation on the resisivity of single crystal and polycrystalline $\mathrm{V}_{3}$ Si. Presented at AIME Fall Meeting, Chicago, Oct. 1977 (BNL 22823). 


\section{RADIATION DAMAGE}
FY 1977: $\$ 160,000$
Principal Investigators: C. L. Snead, Jr.
FY 1978: $\$ 200,000$
Sponsor: Basic Energy Sciences (DOE)

\section{Objective:}

The objective of this study is to develop an understanding of the physical mechanisms that relate radiation-induced lattice defects in type-II superconductors to the superconducting critical properties, and to apply positron-annihilation techniques to study defects.

\section{Srnpe:}

Since the normal-state resistivity is increasingly seen to be a key physical parameter in determining critical properties, neutron and charged-particle irradiations and anneals with temperatures and fluences of parameters provide a most effective investigative approach. The determination of the influence that lattice defects have on the critical properties of NbTi and the A-15 compounds is necessary to their use in radiation environments, and to the understanding of the metallurgy necessary to produce advanced superconducting materials, especially with regard to the A-15's. Modern filamentary wires and wellcharacterized films are irradiated at several facilities, and $T_{c}$ and resistivity measurements or $I_{c}$ measurements at high magnetic fields are performed. Another aspect of the radiation-damage program relates to the application of existing and evolving positron-annihilation techniques to defects. Specific topics addressed here are the investigation of properties of voids, migration and bubble formation of gases injected into metals, and the determination of vacancyimpurity binding energies in alloy systems. 
Significant Accomplishments in 1977:

1. Changes in critical current $\mathrm{I}_{c}$, in $\mathrm{NbTi}$ and $\mathrm{Nb}_{3} \mathrm{Sn}$ caused by low temperature $30 \mathrm{GeV}$ proton irradiation were determined.

2. On the basis of annealing results, it was established that the changes in normal-state resistivity are the key parameter in the mechanism responsible for the changes in $I_{c}$.

Principal Activities P1anned for 1978:

1. The role of defects and normal-state resistivity in irradiated A-15's, especially in the pseudobinary $\mathrm{Nb}_{3}(\mathrm{SnGa})$, will be determined.

Publications in 1977:

Journal Articles

Snead, C. L., Jr., Parkin, D. M., Guinan, M. W., and van Konynenburg, R. A. Determination of the damage-energy cross section of $14 \mathrm{MeV}$ neutrons from critical property changes in irradiated $\mathrm{Nb}_{3} \mathrm{Sn}$. Proc. of the 2nd Topical Meeting on the Technology of Controlled Nuc. Fusion VI, 229 (1977).

Snead, C. L., Jr. Changes in the upper critical fields and critical currents of $\mathrm{Nb}_{3} \mathrm{Sn}$ and $\mathrm{v}_{3} \mathrm{Ga}$ owing to neutron radiation damage. Appl. Phys. Letters 30, $662(1977)$.

Snead, C. L., Jr., Nicolosi, L., and Tremel, W. Effects of $30 \mathrm{GeV}$ proton irradiation on the critical currents of NbTi multifilament wire. Appl. Phys. Letters 31,130 (1977).

Grynszpan, R., Lynn, K. G., Snead, C. L., Jr., Goland, A. N., and Wiffen, F. W. Positron-annihilation investigation of high-temperature neutronirradiated molybdenum. Phys. Letters 62A, 459 (197\%).

Gurvitch, M., Ghosh, A. K., Snead, C. L., Jr., and Strongin, M. Measurements of gap anisotropy in $\mathrm{A}-15 \mathrm{Nb}_{3} \mathrm{Sn}$. Phys. Rev. Letters 39, 1102 (1977). 
Snead, C. L., Jr. Low-temperature $30 \mathrm{GeV}$ proton effects on critical properties of type-II superconducting filamentary conductors. J. Nuc1. Mater. in press (BNL 22778).

Ghosh, A. K., Wiesmann, H., Gurvitch, M., Lutz, H., Kammerer, 0. F., Snead, C. L., Jr., Goland, A. N., Strongin, M. The effects of $\alpha$ irradiation at cryogenic temperatures and electron irradiation on $\mathrm{T}_{c}$ and the transport properties of A-15 superconductors. J. Nucl. Mater. in press (BNL 23140).

\section{Oral Presentations}

Snead, C. L., Jr., Lynn, K. G., Goland, A. N., Grynszpan, R., and Wiffen, F. W. Investigation of voids in neutron irradiated molybdenum using positron annihilation. Presented at APS Spring Meeting, San Diego, Mar. 1977 (BNL 22214). 
PHYSICAL METALLURGY OF METAL HYDRIDES SYSTEMS
FY 1977: \$0
Principal Investigators:
D. Dew-Hughes
M. Pick
FY 1978: $\$ 100,000$
Sponsor: Basic Energy Sciences (DOE)

Objective:

The objective of this study is to gain a fundamental understanding of the metallurgical factors influencing the hydriding behavior of certain metal systems.

\section{Scope:}

Metal hydrides have been suggested for use as energy storage media and the hydriding behavior of many systems has been extensively studied. These investigations, however, rarely are accompanied by proper metallurgical characterization of the hydride-forming metal. It is proposed to study the hydriding behavior on materials of known microstructure, and to deliberately control microstructure, i.e., grain size and distribution of second parameters. Another vital area, which also has been virtually neglected, is the role that surface films play in the formation and decomposition of a metal hydride. Accordingly, surface studies will be initiated to monitor surface contamination before and during hydriding, and to study activation and poisoning of the surface.

\section{Significant Accomp1ishments in 1977:}

1. The structure of $B-F e T i$ hydride has been solved using elastic neutron diffrartion in the monodeutride.

Principal Activities P1anned for 1978:

1. Noble gas isotherms wi.1 be used to study surface effects on the hydriding properties of various metals and alloys. 
2. Kinetics of the hydriding-dehydriding process in FeTi and NiTi will be studied by transmission electron microscopy techniques.

3. The crystal structure of the $B$ and $\gamma$ phase of CoTi and NiTi will be determined.

\section{Publications in 1977:}

Journal Articles

Fenzl, H. F., Pick, M. A., and Wenzl, H. Investigation of the precipitation morphology in the $\alpha+\alpha^{\prime}$ two-phase region of the niobium-hydrogen system by Y-ray diffraction. Scr. Meta11. 11, 271 (1977).

Pick, M. A. and Wenzl, H. Physical metallurgy of FeTi-hydride and its behavior in a hydrogen storage container. Int. J. Hydrogen Energy 1, 413 (1977).

Pick, M.A., Arnold, G., Lebjanft, E., Topler, J., and Wenz1, H. Properties of FeTi-hydrides used for hydrogen storage. Hydrogen Met. Proc 2nd Int. Congr. Vol 8, Pergamon Press, NY, (1977).

Welter, J.M., Pick, M. A. Schober, T., Hanck, J., Fenz1, H.F., and Wenz1, W. Investigations of the phase diagram of the $\mathrm{Nb}-\mathrm{H}$ system. Hydrogen Met. Proc. 2nd Int. Congr. Vol. 7, Pergamon Press, NY, (1977).

Pick, M.A., Bickman, K., Potah1, E., Zwo11, K., and Wenzl, H.A. A new automatic triple-crystal $x$-ray diffractometer for the precision measurement of intensity distribution of Bragg diffraction and Huang scattering. .T. App1. riryst. $\underline{10}, 950(1977)$.

\section{In Press}

Thompson, P., Pick, M. A., Reidinger, F., Cor1.iss, L., Hastings, J., and Reilly, J. J. Neutron diffraction study of B-iron-titanium-deuteride. J. Phys. F. in press (BNL 23825). 
EFFECTS OF MICROSTRUCTURES AND ENVIRONMENT UPON FRACTURE TOUGHNESS
FY 1977: \$0
Principal Investigators:
D. Dew-Hughes
A. Arbel
FY 1978: $\$ 100,000$
Sponsor: Basic Energy Sciences (DOE)

Objective:

The objective of this program is to study the relationship between microstructures and fracture toughness of metals and alloys.

Scope:

Fracture toughness is considered as a material property with values that are specified in modern designs of energy-related structural components. The purpose of this program is to make a fundamental study on the relationship between microstructures and fracture toughness. In particular, effects of microstructural changes, which are developed during fatigue type loading and high temperature creep processes, on fracture toughness of simple materials will be investigated. The program will also be extended to fracture studies of materials which were fatigued and creep-loaded in various environmental atmospheres such as may be encountered in service of energy-related installations. The novelty of the present program is the $\mathrm{fact}$ that fracture toughness is studied in materials after exposure to various stages of simulated service conditions and not only in their virgin stage before they are put into service. It is expected that this program will generate information leading to a new approach of evaluating performance of engineering materials.

Significant Accomplishments in 1977:

1. Mechanical testing apparatuses were purchased and have been set up for tests. 


\section{Principal Activities Planned for 1978:}

1. The effect of microstructures developed by creep and strain-controlled fatigue on fracture toughness will be determined on commercially pure nickel and a stable solid solution of nickel-chromium-molybdenum superalloy.

Publications in 1977:

None. 
SUPERCONDUCTING MAGNET CONDUCTOR DEVELOPMENT FABRICATION AND

PROPERTIES OF CONDUCTORS FOR MFE MAGNETS

FY 1977: $\$ 200,000$

FY 1978: $\$ 200,000$
Principal Investigators:

T. S. Luhman

M. Suenaga

W. B. Sampson

Sponsor: Basic Energy Sciences (DOE)

\section{Objective:}

The objective of this program is to develop suitable and economical conductors for mirror and Tokamak Fusion Reactor magnets.

\section{Scope:}

It appears that $\mathrm{Nb}_{3} \mathrm{Sn}$ is required at least inside the highest field regions (10.0 tesla and above) for plasma confinement. Since $\mathrm{Nb}_{3} \mathrm{Sn}$ is brittle, the superconducting properties of conducters made from it are susceptible to degradation when mechanically strained. The conductor may be strained during fabrication or during operation by the Lorentz forces. Thus, it is important to the development of procedures for magnet construction to study response of the superconductors to applied strains at room and helium temperatures and to understand the mechanisms leading to degradation. Furthermore, development of composite conductors, in which degradation is minimized without sacrificing critical current densities, is a primary requisite for the successful design and construction of Magnetic Fusion Energy magnet systems.

Development of composite superconductors requires an understanding and control of all aspects of fabrication and assembiy. Thus, this program focuses on (a) determining the degradation mechanisms of superconductors subjected to mechanical strains, (b) development of composite conductors and fabrication meth- 
ods to minimize degradation, and (c) development of other more attractive high field' conductors.

Significant Accomplishments in 1977:

1. It was shown that $\mathrm{Nb}_{3} \mathrm{Sn}$ wires can sustain an elongation of $\checkmark 1.0 \%$ without degradation of $J_{c}$ if a proper ratio of the matrix to the core is chosen. Principal Activities Planned for 1978:

1. Effects of cabling on the mechanical properties of $\mathrm{Nb}_{3} \mathrm{Sn}$ wires will be investigated.

2. With completion of a $10 \mathrm{~T}$ split pair magnet, effects of tensile strain on superconducting critical currents of $\mathrm{Nb}_{3} \mathrm{Sn}$ wires will be measured at high fields up to $10 \mathrm{~T}$.

Publications in 1977:

Luhman, T. S., Suenaga, M., and Klamut, C. J. The influence of tensile stresses on the superconducting temperature of monofilamentary $\mathrm{Nb}_{3} \mathrm{Sn}$ composite conductors. Cryog. Eng. in press (BNL 23016).

\section{Oral Presentations}

Luhman, T. S., Sueaga, M., and Klamul, C. J. In silu supercunducting and mechanical properties measurements of $\mathrm{Nb}_{3} \mathrm{Sn}$ wire conductors. Presented at APS Spring Meeting, San Diego, Mar. 1977 (BNL 22155).

Luhman, T. S., Suenaga, M., and Klamut, C. J. The effect of bronze to niobium ratios on the $4.2 \mathrm{~K}$ tensile strain degradation of monofilament $\mathrm{Nb}_{3} \mathrm{Sn}$ superconductors. Presented at AIME Fall Meeting, Chicago, Oct. 1977 (BNi $22705)$. 


\section{SUPERCONDUCTING POWER TRANSMISSION LINES*}

FY 1977: $\$ 350,000$

FY 1978: $\$ 400,000$
Principal Investigators: J. F. Bussiere, C. Klamut, A. Muller, M. Suenaga,

D. H. Gurnisky

Sponsor: Electric Energy Systems (DOE)

Objective:

The objective of this program is to develop superconducting and dielectric tapes for ac superconducting power transmission lines.

\section{Scope:}

This study includes the investigation of fabrication processes for superconducting tapes suitable for ac $(60 \mathrm{~Hz})$ applications, of mechanisms for ac losses in A-15 compounds, of relationship between microstructures to the losses, and of mechanical properties of the tapes. In addition, new processes for the conductor fabrication will be transferred to industries, and the contracts for commercialization of the processes will be monitored.

The major effort of the dielectric tape development program is an investigation of dielectric materials to provide tapes that are electrically, mechanically, and thermally suitable for use as insulation on ac superconducting cables. Also being developed and applied is a radiographic technique to study tape-lapping patterns and to locate mechanical defects in existing cables. Measurements of mechanical (strength, friction, etc.) and thermal (expansion coefficients) properties of these tapes are made at room as well as 1 iquid helium temperatures.

Significant Accomplishments in 1977:

1. Ac losses due to the unreacted $\mathrm{Nb}$ substrate were identified and investigated experimentally as well as theoretically. 
2. A process for fabricating 4-mil-thick, laminated, high-modulus, polypropylene films for cable use was developed.

3. Cable radiography was successfully used in the field to monitor the quality of new underground paper-oil cables.

Principal Activities P1anned for 1978:

1. Superconducting tapes with improved mechanical properties will be deve1oped, and the tape for a 100-m test line will be ordered.

2. Very high modulus polyethylene tapes will be developed.

3. Addition of digital processing equipment to the $x$-ray radiography system will be made to achieve real time displays of cable structures.

Publications in 1977:

Journal Articles

Bussiere, J. F. The development of low loss $\mathrm{Nb}_{3} \mathrm{Sn}$ for ac power transmission: a review. IEEE Trans. Magn. MAG-13, 131 (1977).

Suenaga, M., Klamut, C. and Bussiere, J. F. Ac loss and de critical current densities of $\mathrm{Nb}_{3} \mathrm{Sn}$ tapes by the solid state diffusion process. IEEE Trans. Magn. MAG-13 $436(1977)$.

Bussiere, J. F., Kovachev, V., Klamut, C., and Suenaga, M. $\mathrm{Nb}_{3} \mathrm{Sn}$ conductors for ac power transmission: electrical and mechanical characteristics. Prog. Cryog. Eng. in press (BNL 22962).

Bucoicre, J. F., Ouishi, T., Welch, U. O., and Suenaga, M. Stress-induced enhancement of $\mathrm{T}_{c}$ in bronze-processed $\mathrm{V}_{3} \mathrm{Ge}$. Appl. Phys. Letters, submitted for publication (BNL 23723;.

Subbi,ere, J. F. and Kovachev, V. T. Surface effects affecting ac 1 osses of $\mathrm{Nb}_{3} \mathrm{Sn}$. J. App1. Phys. submitted for publication (BNL 23447). 


\section{Oral Presentations:}

Muller, A. C. An x-ray method for studying butt gap distribution and spliced joints in lapped paper and plastic cable. Presented at the Winter Meeting of IEEE Power Eng. Soc., New York, Jan. 1977 (BNL 21824).

Bussiere, J. F. and Suenaga, M. Influence of bronze matrix on $T_{c}$ and ac losses of $\mathrm{Nb}_{3} \mathrm{Sn}$ tapes. Presented at APS Spring Meeting, San Diego, Mar. 1977 (BNL 23723).

Bussiere, J. F., Onishi, T., Welch, D. O., and Suenaga, M. Stresses and critical temperature, $\mathrm{T}_{\mathrm{c}}$, of bronze processed $\mathrm{Nb}_{3} \mathrm{Sn}$ and $\mathrm{V}_{3} \mathrm{Ge}$. Presented at AIME Fal1 Meeting, Chicago, Oct. 1977 (BNL 22712).

* * This represents an effort by the Division of Metallurgy and Materials Science for the program by the same title in the Accelerator Department. 
INTERGRANULAR STRESS CORROSION OF IRON AND NICKEL-BASE ALLOYS*

FY 1977: \$0

FY 1978: $\$ 60,000$
Principal Investigator: A Winter

Sponsor: Basic Energy Sciences (DOE)

Objective:

The objective of this study is an understanding of the influence of grain boundary precipitates on intergranular stress corrosion (ISC) of iron (Fe) and nickel (Ni) base alloys.

\section{Scope:}

ISC in $\mathrm{Fe}$ and $\mathrm{Ni}$ alluys is a unfverial problem in the use of these alloys in energy conversion. Its occurrence has been wi despread in both foosil- and nuclear-fueled power plantts and can be anticipated to occur in advanced reactors, and in solar or geothermal power generators as we11. The phenomenon is of concern in the performance of steam generators, steam-driven turbine components, and steam lines, which are common to all types of cncrgy conversion syslems that utilize a steam cycle. Intergranular stress corrosion arises from an electrochemical cell being set up, in a given environment, at the grain boundary of the alloy. This, for reasons that are not we 11 understood, causes continued corrosion of the grain boundary materia1. The stress cauece local depassivation of the material by rupturing the passivating oxide films, and retards repassivation. In this sense there is believed to be a direct competition beLween the electrochemical dissolution along the grain boundary and the repassivation reactions; an understanding of this competition can lead to improved performance of materials by modifications to their composition and environment. The most important environments to investigate are those that either are oxidizing or contain dissolved caustics. 
Significant Accomplishments in 1977:

1. For the first time, chromium-depleted zones adjacent to high angle grain boundaries in' sensitized stainless steels were measured.

Principal Activities P1anned for 1978:

1. Studies of depleted zones adjacent to grain boundaries in steels, and Inconel and Incoloy will be studied.

Publication in 1977:

Journal Articles

Pande, C. S., Suenaga, M., Vyas, B., Isaacs, H. S., and Harling, D. F. Direct evidence of chromium depletion near the grain boundaries in sensitized stainless steels. Scr. Meta11. 11, 681 (1977).

* This represents an effort by the Division of Metallurgy and Materials Science for the program by the same title in the Department of Nuclear Energy.

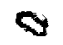


Programs Proposed for Initiation in FY 1979

In addition to the programs summarized above, the Metallurgy and Materials Science Division has proposed to undertake several new programs in FY 1979. These are 1 isted by title below:

Basic Process in Amorphous Semiconductor Thin Films for Solar Energy Conversion

Effects of High Temperature Creep and Fatigue on Fracture Toughness of Engineering Superalloys.

SANS (Sma11 Angle Neutron Scattering) for Examining and Evaluating Materials.

Solar Thermal Energy Conversion-Thin Film Amorphous Semiconductor Coatings for Solar Thermal Conversion.

0 


\section{PROCESS SCIENCES DIVISION}

Meyer Steinberg

The Process Sciences Division is concerned with the application of scientific and engineering principles for the development of processes dealing with energy production and conversion. Current programs include the areas of fuel production, conservation, and environmental problems.

Included under energy and fuel production are the development of a coal hydrogenation process, the development of improved materials for construction for use in geothermal electrical generation and process and district heating applications, and the development of high-temperature cementing materials for use in the completion of geothermal and deep oil wells.

Energy conservation programs include an advanced process for the production and characterization of low energy copolymers and the use of recycled solid wastes as substitutes for energy-intensive materials of construction.

Environmentally oriented programs in progress include methods for the regeneration of limestone used in coal desulfurization processes for application to fluidized bed combustion and analysis of control technology problems related to coal conversion and global $\mathrm{CO}_{2}$ emissions.

Structurally, the Division is divided into three units: Materials Systems Group, Fossil Energy Sciences Group, and a Process Analysis and Advanced Energy Systems Section. 
FLASH HYDROPYROLYSIS OF COAL TO GASEOUS AND LIQUID HYDROCARBON PRODUCTS
FY 1977: $\$ 250,000$
Principal Investigators:
M. Steinberg
P. Fallon
FY 1978: $\$ 257,000$
Sponsor: Fossil Energy (DOE)

\section{Objective:}

The objective of this program is to obtain process chemistry information required for the development of a Flash Hydropyrolysis Process (FHP) for the conversion of coal to liquid and gaseous hydrucarbon produces.

\section{Scope:}

The program is designed to obtain process chemistry and design information on the FHP of coal, a rapid gas-phase, noncatalytic coal hydrogenation technique developed at BNL. The basis of the process is a rapid heating of coal followed by a rapid quench of the reaction products, maximizing the liquid products consisting mainly of benzene. Coproducts of methane and ethane are also formed.

Presently, a parametric study of product yields and distribution using lignite is being conducted. The variables include temperatures between $500^{\circ}$ and $900^{\circ} \mathrm{C}$, hydrogen pressures between 500 and $4000 \mathrm{psi}$, coal particle residence times from < 1 to $\geq 10 \mathrm{sec}$, and hydrogen to coal feed ratio of 0.5 to 2.0 . Experiments will also be conducted using sub-bituminuous coals. A number of exploratory runs will be conducted to include the use of catalyst and recycled char and ash in an effort to improve hydrocarbon product yields. Bnth gas and coal particle residence times will be studied in greater detail by the use of sample taps placed at 2 -ft intervals along the length of the reactor and by extending the duration of the experimetal runs. A process design and economic 
model will be developed for a full scale FHP plant for production of distillate fuels and pipeline gas.

Significant Accomplishments in 1977:

1. The design and construction of a versatile down-flow tubular reactor system was completed. The reactor is $1 \mathrm{in}$. dia. $x 12 \mathrm{ft}$. 1ong, is capable of feeding up to $2 \mathrm{lb} / \mathrm{hr}$ of coal and $10 \mathrm{lb} / \mathrm{hr}$ of hydrogen, and can operate up to $900^{\circ} \mathrm{C}$ temperature and 4000 psig pressure with on-1ine gas chromatopgraphic analysis.

2. The $2 \mathrm{lb} / \mathrm{hr}$ coal unit was successfully operated over a range of conditions for 90 runs using a lignite feed.

3. Coal conversion, yield, and product distribution data were obtained as a function of pressure, temperature, residence time, and hydrogen-to-coal-feed ratio. Yields based on carbon conversion at $750^{\circ} \mathrm{C}$ and $2000 \mathrm{psi}$ and $<10 \mathrm{sec}$ coal residence time consist of $10 \%$ benzene, $10 \% 1$ ight oil, $25 \%$ methane, $10 \%$ ethane, and $5 \% \mathrm{co}$, for an overall yield of $60 \%$.

4. Data was fitted to the model to indicate the diréction of future experiments.

\section{Principal Activities Planned for 1978:}

1. The parametric study of coal conversion and product distribution data as a function of process variables from 500 to $4000 \mathrm{psig}$ and $500^{\circ}$ to $900^{\circ} \mathrm{C}$ will be completed and the data will be corelated.

2. Exploratory runs using char, ash, and catalysts for improving the hydrocarbon product yields will be performed.

3. Product yield and process chemistry data for bituminous and subbituminous coal will be obtained. 
4. Process design and economic evaluation of a full-scale FHP plant for production of distillate fuels and pipeline gas will be initiated.

Publications in 1977:

BNL Reports

Fallon, P. T. and Steinberg, M. Flash Hydropyrolysis of Coal, Quarterly Report No. 1, January 1 - March 31, 1977, BNL 50677.

Steinberg, M. and Fallon, P. T. Flash Hydropyrolysis of Coal, Quarterly Report No. 2, April 1 - June 30, 1977, BNL 50707.

Steinberg, M. and Fallon, P. T. Flash Hydropyrolysis of Coal, Quarterly Report No. 3, July 1 - September 30, 1977, BNL 50779.

Bhatt, B., Fallon, P. T. and Steinberg, M. Economic analysis of flash hydropyrolysis BNL 22912.

Oral Presentations

Fallon, P. T. and Steinberg, M. F1ash hydropyrolysis of coal--the design, construction, operation, and initial results of a flash hydropyrolysis experimental unit. ACS 173rd National Meeting, New Orleans, March 20-25, 1977. (BNL. 50698).

Steinberg, M. and Fallon, P. T. Flash hydropyrolysis of coal (FHP) -Fossil Energy/ERDA crosscut Meeting, Washington, D. C., Sept. 15, 1977 (BNL 23282). 
REGENERATIVE PROCESS FOR DESULFURIZATION OF HIGH TEMPERATURE

COMBUSTION AND FUEL GASES
FY 1977: $\$ 300,000$
Principal Investigators:
R. T. Yang
M. Steinberg
FY 1978: $\$ 357,000$
Sponsor: Fossil Energy (DOE)

\section{Objective:}

The purpose of this program is to obtain basic process chemistry information required for the development of processes for the regeneration of limestone or lime-based sorbents used in the desulfurization of combustion and fuel gases in power production cycles. Application of regeneration of sulfated limestones to fluidized-bed combustion (FBC) of coal is the specific goal. To identify the existing problems in FBC and to provide solutions and improvements are essential parts of the program.

\section{Scope:}

A major advantage of fluidized bed combustion is its ability to produce a desulfurized hot gas from coal combustion using lime. However, economic and environmental considerations require the regeneration of the calcium sulfate formed. No satisfactory process has been developed as yet.

Laboratory and bench-scale experiments performed in this program provide information for (1) improved lime regeneration processes, (2) new and promising regenerable sorbents for $\mathrm{SO}_{2}$, such as the calcium silicates, (3) improved 1 ime

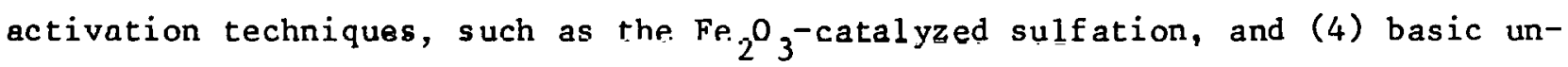
derstanding of the kinetics and mechanisms of the heterogeneous reactions in FBC. All of the above will directly contribute to improving the FBC technology. Kinetics of sulfation and regeneration reactions are being studied in a 1 -atm 
TGA, a 10-atm TGA, and a 1-in. quartz fluidized-bed sulfator. Emission and corrosion aspects of the $\mathrm{NaCl}$-added $\mathrm{FBC}$ are quantitatively studied.

Significant Accomplishments in 1977:

1. The BNL Regeneration Process, which involves reacting sulfated limestone $\left(\mathrm{CaSO}_{4}\right)$ with fly ash from Fluidized Bed Combustion (FBC), was shown to yield a steady $5 \% \mathrm{SO}_{2}$ stream at $1000^{\circ} \mathrm{C} \mathrm{kiln} \mathrm{temperature,} \mathrm{and} \mathrm{the} \mathrm{regenerated}$ stone had a $30 \%$ higher reactivity towards sulfation than the raw stone.

2. An $\mathrm{Fe}_{2} \mathrm{O}_{3}$-catalyzed sulfation process was discovered that has a rate twice as high as that of the conventional process.

3. Galeium silicales were found to have régeneration rates 5 to 10 times higher than those of the Greer lime.

\section{Principal Activities P1anned for 1978:}

1. Experiments on a microrotary kiln (10-g capacity), in which $\mathrm{CaO}$ is regenerated by roasting $\mathrm{CaSO}_{4}$ and $\mathrm{fly}$ ash containing $20 \%$ unburnt carbon, will be completed. The kiln is heated isothermally and externally with a furnace- The results will provide basic understanding of the process.

2. Thermugravimetric and micro-FBC testing will be completed by mid-1978.

3. A process design and analysis of the BNL Regeneration Process will be completed.

4. To obtain information on the sorbent reactivity under fluidized-bed combustion conditions, design and construction of a 2 in.-dia. combustor and a rotary kiln with comparable capacity will be initiated. These are all for batch-wise operation and will be used for cyclic studies. 
Publications in 1977:

Journal Articles

Yang, R. T., Steinberg, M., and Krishna, C. R. Fluidized-bed coal combustion with lime additives. The phenomenon of peaking of sulfur retention at a certain temperature. Ind. Eng. Chem. Fundamentals, 16, (4) 465 (1977).

Yang, R. T., Shen, M-S., and Steinberg, M. Regenerative limestone process for fluidized-bed combustion. Ind. Eng. Chem. Proc. Des. Dev. in press (BNL 22782).

Yang, R. T., Shen, M-S., and Steinberg, M. Fluidized-bed combustion of coal with lime additives. Catalytic sulfation of lime with iron compounds and coal ash. Environ. Sci. Technol., in press (BNL 23476).

\section{$\underline{\text { BNL Reports }}$}

Yang, R. T. et al. Regenerative Process for Desulfurization of High Temperature Combustion and Fuel Gases, Quarterly Reports, No. 1 - progress letter, No. 2 (BNL 50582), No. 3 (BNL 50620), No. 4 (BNL 50699), No. 5 (BNL 50706), No. 6 (BNL 50750), No. 7 (BNL 50809).

\section{Oral Presentations}

Yang, R. T., Shen, M-S., and Steinberg, M. Regeneration of lime for f1uidized-bed combustion with carbon, with silica, and with coal ash. Proc. Fluid-Bed Combust. Technol. Exchange Workshop, NTIS Conf.-77-447, 2, 313 (1977).

Yang, R. T., Chen, J. M., Farber, G., Shen, M-S., and Steinberg, M. Regeneration of lime-based sorbents in a kiln with solid reductants. Presented at 5th Int. Conf. Fluid.-Bed Combust. Washington, D. C., Dec. 12-14, 1977 (BNL $23765)$. 
GEOCHEMICAL ENGINEERING, ALTERNATE MATERIALS OF CONSTRUCTION

FOR GEOTHERMAL APPLICATIONS
FY 1977: $\$ 220,000$
Principal Investigator: L. E. Kukacka
FY 1978: $\$ 230,000$
Sponsor: Geothermal Energy (DOE)

\section{Objective:}

The objective of the program is to develop low-cost nonmetallic materials such as polymers, concrete polymer composites, and refractory cements for use as materials of construction in geothermal processes.

\section{Scope:}

A serious problem in the development of geothermal energy is the availability of durable and economic materials of construction for handling hot brine and steam. Hot brine and other aerated geothermal fluids are highly corrosive and they chemically attack most conventional materials of construction. Corrosion and scaling have been encountered in a 11 geothermal planto, and to vailuus de= grees, they adversely affect plant lifetimes and power output. To date, carbon steel has been the primary material used, but expensive materials, such as stainless steels and titanium base alloys, may be required for long-term operation.

The purpose of the program is to identify areas in geothermal processes where nonmetallic materials may be utilized in a cost-effective manner and to develop and test these materials under laboratory and field conditions. To date, polymer concrete systems have been formulated and laboratory and field tests performed in brine, flashing brine, and steam at temperatures up to $260^{\circ} \mathrm{C}$. Data for exposule limes of 2 years are available. Good durability is indicated. Eco- 
nomic studies indicate that the use of the materials can result in reductions in power costs of $\sim 10 \%$.

Significant Accomplishments in 1977:

1. Polymer concrete composites were developed which have high strength and durability to brine at temperatures up to $260^{\circ} \mathrm{C}$.

2. Field evaluations of test specimens and lined pipe were started at six geothermal sites.

3. Economic studies identified several cost-effective uses for the materials in geothermal power plants. Reductions in the cost of power of $\checkmark 6$ mills per $\mathrm{kWh}$ were calculated.

\section{Principal Activities for 1978:}

1. Field tests will be initiated in additional geothermal environments.

2. Tests to optimize the polymer concrete formulations with respect to the anticipated environmental conditions and cost will be completed.

3. Prototype sections of pipe and vessels will be placed into test.

4. Economic studies to determine the cost effectiveness of using the materials in nonelectric geothermal processes will be performed.

Publications in 1977:

BNL Reports.

Steinberg, M., Kukacka, L. E., Fontana, J., Horn, W., Amaro, J., and Sugama, T. Alternate Materials of Construction for Geothermal Applications, Progress Report No. 11, October-December 1976, BNL 50627.

Sţeinberg, M., Kukacka, L. Ë., Fontana, J., Horn, W., Amaru, J., and Sugama, T. Alternate Materials of Construction for Geothermal Applications, Progress Report No. 12, January-March 1977, BNL 50665. 
Steinberg, M., Kukacka, L. E., Fontana, J., Horn, W., Amàro, J., and Sugama, T. Alternate Materials of Construction for Geothermal Applications, Progress Report No. 13, Apri1-June 1977, BNL 50699.

Steinberg, M., Kukacka, L. E., Fontana, J., Horn, W., Amaro, J., Sugama, T., Carciello, N., and Zeldin, A. Alternate Materials of Construction for Geothermal Applications, Progress Report No. 14, July-September 1977, BNL 50751. Kukacka, L. E. Economic Assessment of Polymer Concrete Usage in Geothermal Power Plants. Burns \& Roe Industrial Services Corporation, November, 1977, BNL 50777.

\section{Oral Presentatiuris}

Kukacka, L. E. The applicability of concrete polymer materials for use in geothermal environments. Presented at the Society of Petroleum Engineers of AIME, Int. Symp. Oilfield and Geothermal Chemistry, San Diego, June 27-29, 1977 BNL 22684. 
GEOCHEMICAL ENGINEERING, CEMENTING OF GEOTHERMAL WELLS

$\begin{array}{ll}\text { FY 1977: } \$ 243,000 & \text { Principal Investigator: L. E. Kukacka } \\ \text { FY 1978: } \$ 500,000 & \text { Sponsor: Geothermal Energy (DOE) }\end{array}$

\section{Objective:}

The objective of the program is to develop high temperature cementing materials for use in the completion of geothermal wells and deep oil and gas wells.

\section{Scope:}

The cementing of a well is considered to be the most critical single aspect in the development of a geothermal source. Portland or other forms of hydrated cement that are most widely used today do not exhibit good durability. Also, large variations in the cure time occur between batches of cement. Premature setting of the cement is not uncommon and results in plugging of the well, which necessitates costly redrilling.

Technical discussions with the geothermal industry indicated that a coordinated DOE-sponsored program for the development of cements designed specifica11y for geothermal applications was needed. To satisfy this need, BNL has developed and is managing a program on well-cementing materials. The program goals are heing achieved by performance of the following tasks:

1. Development of inorganic and organic well-cementing materials capable of withstanding the environmental conditions in geothermal wells.

2. Development of the technology required to mix, pump, and place the cementing materia1.

3. Testing of the materials in down-hole test facilities.

4. Demonstration of the process by the cementing of prototype wells. 
The work at BNL involves in-house research on polymer-concrete cementing materials as well as full management of an integrated program involving subcontract efforts and industrial participation.

\section{Significant Accomplishments in 1977:}

1. A management plan for the development of new cementing materials specifically oriented to geothermal we11s was prepared. Program milestones were identified and a milestone timeline chart produced. The funding level required to attain the program goals was determined.

2. Work to implement the program plan was initiated. In-house research on organic cements was started at BNL. Five subcontracts for research on inorganic cements were initiated.

Principal Activities Planned for 1978:

1. Technical management of the entire well-cementing program will be continued.

2. High temperature organic cements will be selected and the technology to pump and place them will be developed.

3. Construction of down-hole testing facilities will commence.

4. Testing of inorganic cements will continue and priorities established for down-hole evaluatinn.

Pub1ications in 1977:

BNL Reports

Steinberg, M., Kukacka, L. E., Fontana, J., Zeldin, A., and Carcie11n, N. Cementing of Geothermal Wells, Progress Report No. 3, October-December 1976, BNL 50621 
Steinberg, M., Kukacka, L. E., Fontana, J., Zeldin, A., Carciello, N. and Sugama, T. Cementing of Geothermal We11s, Progress Report No. 4, January-March 1977, BNL 50627..

Steinberg, M., Kukacka, L. E., Fontana, J., Zeldin, A., Carciello, N. and Sugama, T. Cementing of Geothermal Wells, Progress Report No. 5, April-June 1977, BNL 50693.

Steinberg, M., Kukacka, L. W., Fontana, J., Zeldin, A., Carciello, N. and Sugama, T. Cementing of Geothermal We11s, Progress Report, No. 6, JulySeptember 1977, BNL 50738.

\section{Oral Presentations}

Kukacka, L. E. The applicability of concrete polymer materials for use in geothermal environments. Presented at the Society of Petroleum Engineers of AIME, Int. Symp. Oilfield and Geothermal Chem., San Diego, June 27-29, 1977 (BNL 22684). 
IMPLEMENTATION OF CONCRETE POLYMER RESEARCH ON REPAIR OF DETERIORATED CONCRETE

FY 1977: $\$ 120,000$

FY 1978: $\$ 165,000$
Principal Investigators: L. E. Kukacka

Sponsor: Implementation Division, Federal Highway Administration

\section{Objective:}

The objective of the program is to develop and transfer the technology necessary for the utilization of concrete-polyuer materials in highway applications.

\section{Scope:}

The increased use of chloride deicing salts in recent years has resulted in the rapid deterioration of concrete bridge decks. Penetration of the chlorides into the concrete results in the corrosion of the reinforcing stee 1 . The corrosion increases the volumn of the steel, which causes spalling and cracking of the concrete.

The high cost of repairing deteriorated bridge decks has resulted in a concerted research effort to find materiale for the preventiun and repair of this damage. This research has shown that concrete-polymer materials are one group of materials that show promise in helping to alleviate this problem.

The current program provides the technical guidance necessary so that designated State highway agencies can successfully utilize concrete-polymer materials. The work involves the development and refinement of methods for using polymer materials under field conditions, and it includes working with State highway agencies to develop operational procedures for utilization of these materials. 


\section{Significant Accomplishments in 1977:}

1. Technical assistance on the use of concrete polymer materials was provided to several State agencies.

2. A thin polymer concrete overlay system for bridge deck applications was developed and field testing initiated.

3. A User's Manual describing procedures for the use of polymer concrete patching materials was prepared and issued.

Principal Activities Planned for 1978:

1. The technology for the use of polymer concrete to repair delaminatd concrete will be developed.

2. The technical assistance effort will be expanded.

3. A User's Manual describing the method for applying polymer concrete overlays on bridge decks will be prepared.

Publications in 1977:

BNL Reports

Webster, R., Kukacka, L. E., Steinberg, M., Fontana, JJ., and Arnold, G. Implementation of Concrete-Polymer Research on Repair of Deteriorated Concrete, Phas II, Progress Report No. 1, October-December 1976, BNL 22384.

Webeter, R., Kukarka, L. E., Steinberg, M., Fontana, J., and Arnold, G. Implementation of Concrete-Polymer Research on Repair of Deteriorated Concrete, Phase II, Progress Report No. 2, January-March 1977, BNL 22687.

Webster, R., Kukacka, L. E., Steinberg, M., Fontana, J., and Arnold, G. Implementation of Concrete-Polymer Research on Repair of Deteriorated Concrete, Phase II, Progress Report No. 3, April-June 1977, BNL 23174. 
Webster, R., Kukacka, L. E., Steinberg, M., Fontana, J., and Arnold, G. Implementation of Concrete-Polymer Research on Repair of Deteriorated Concrete, Phase II, Progress Report No. 4, July-September 1977, BNL 23570.

Kukacka, L. E. and Fontana, J. Polymer-Concrete Patching Materials, Vol. I User's Manual. FHWA 77-11, Vol. I, April 1977.

Kukacka, L. E. and Fontana, J. Polymer-Concrete Patching Materials, Vol. II Final Report. FHWA 77-11, Vo1. II, April 1977.

\section{Oral Presentations}

Kukacka, L. E. Production methods and applications for concrete-polymer materials. Presented at AIChE National Meeting, New York, Nov. 13-17, 1977 (BNL $22640)$

Kukacka, L. E. Applications of concrete polymer materials for the rehabilitation of bridge decks. Presented at World of Concrete Symposium, Phoenix, Arizona, Jan. 10, 1978 (BNL 23496).

Kukacka, L. E. Concrete polymer materials, production methods and applications. Presented at World of Concrete Symposium, Phoenix, Arizona, Jan. 13, 1978 (BNL 23497). 


\section{AGGREGATES BY MATERIALS IMPREGNATION}

$$
\begin{array}{ll}
\text { FY 1977: } & \$ 40,000 \\
\text { FY 1978: } & \$ 80,000
\end{array}
$$$$
\text { Principal Investigator: J. Fontana }
$$

Sponsor: Materials Division, Federal Highway Administration

\section{Objective:}

The objective of the program is to select and evaluate materials and impregnation techniques for the improvement of the wear-resistance properties of natural aggregates.

\section{Scope:}

In the interest of highway safety and energy conservation, it is essential that durable pavement surfacing systems with high skid resistance under severe traffic conditions be developed. For this application, high strength aggregate with a high resistance to polishing and weathering is required. Unfortunately, natural aggregates having these properties are not available in many areas, necessitating high shipping costs.

Earlier BNL work had shown that considerable improvement in the durability and strength of aggregate could be obtained by impregnation with organic and inorganic materials. Therefore, a composite consisting of a we11-bonded plasticlike material dispersed in the vesicularity or porosity of the aggregate should be extremely durable. Under traffic conditions, the composite would be expected to wear differentially, thereby maintaining its skid-resistance characteristics.

The current program inoludes the selertion and evaluation of impregnation materials and processes, evaluation of the physical and mechanical properties of the treated aggregates, and small-scale field testing of promising systems. 
Significant Accomplishments in 1977:

1. A bibliography on the characteristics of natural aggregates and potential impregnants was prepared.

2. Aggregate samples were obtained from various geological areas of the United States. These included igneous and metamorphic rocks from the East and West, and sedimentary rocks from the Midwest and Plains states.

3. Tests to measure the skid-resistance characteristics of the above materials, before and after impregnation, were initiated.

Principal Activities for 1978:

1. The selection of inorganic and organic materials and processes for use in the production of impregnated aggregate will be completed.

2. The characterization of natural and impregnated aggregates will be continued.

3. Circular track-type accelerated wear-polish tests will be performed on pavement mixtures containing the most promising impregnated aggregates.

Publications in 1977:

None 
ENCAPSULATION OF PHASE-CHANGE MATERIALS IN CONCRETE MASONRY CONSTRUCTION

FY 1977: \$ 52,000

FY 1978: $\$ 120,000$
Principal Investigators:

L.E. Kukacka

M. J. Sansone

Sponsor: Energy Storage (DOE) (subcontract from Oak Ridge National Laboratory)

\section{Objective:}

The objective of the program is to develop the techniques for producing energy storage systems by the microencapsulation of phase-change materials into concrete masonry materials.

\section{Scope:}

Space conditioning is the major energy-consuming function required by residential and commercial buildings:" Potential impacts of proposed energy conservation approaches could result in national savings that substantially exceed the Btu equivalent of millions of barrels of oil annully. These anticipated savings can be derived from the use of space-conditioning system modifications that provide increased overall efficiency of heating and cooling devices, the use of improved thermal management practice, and the optimum use of national electric generating capacity. Central to all these approaches to energy conservation in huildings is the sophisticated use of thermal storage.

An excellent means of energy storage is to utilize the latent heat of materials undergoing phase changes. DOE-sponsored research has identified several promising materials which, if methods for incorporating them into masonry are developed, will significantly increase the heat capacity of the structure.

The encapsulation of a phase-change material (PCM) in concrete offers a method for producing a low-cost energy storage system that can be manufactured with only small modifications to existing processes. Normal weight concrete con- 
sists of $s 80$ wt $\%$ aggregate. Therefore, the greatest and most uniform concentration of a PCM within a concrete masonry structure can be attained by using the material as partial replacement for the normal fine and coarse aggregate. To accomplish this, the PCM must be immobilized and capable of interacting with the binder to produce a high strength and low permeability concrete. It is also essential that the PCM not react chemically with the aggregate and be noncorrosive to steel reinforcement.

On the basis of earlier work performed at BNL, it appears that the criteria for encapsulating PCM into masonry can be met by the use of concrete-polymer technology. Immobilization of salts used as aggregate in polymer concrete has already been demonstrated. In the current program, techniques for incorporating the PCM in various forms of masonry materials will be developed and the materials characerized by measuring their mechanical, physical, and chemical properties. Economic studies will also be initiated.

Significant Accomplishments in $1977:$

This is a new program which was initiated in September 1977. Prillipal Aclivities Planned tor $19 / 8$ :

1. Materials that undergo a solid-liquid transformation in the temperature range $18^{\circ}$ to $25^{\circ} \mathrm{C}$ will be identified and techniques for the microencapsulation of the materials in concrete, polymer concrete, and polymer-impregnated concrete will be developed.

2. The mechanical and physical properties of the composites will be measured.

3. Economic studies will be performed to determine the processing costs associated with the encapsulation of phase change materials in masonry construction. 
Publications in 1977:

None. 
DEVELOPMENT OF A GLASS-POLYMER COMPOSITE SEWER PIPE FROM WASTE GLASS
FY 1977: \$ 55,000
Principal Investigator: L.E. Kukacka
FY 1978: $\$ 100,000$
Sponsor: Industrial Energy Conservation (DOE)

\section{Objective:}

The objective of the program is to provide the technical basis for energy conservation by the development, testing, and practical demonstration of products made from waste glass.

\section{Scope:}

Experimental work is being performed to provide the technical basis for energy conservation by the development, testing, and practical demonstration of products made from waste glass. At present, uses for recycled ferrous and nonferrous metals are apparent, but efficient methods for utilizing other components of urban waste such as glass and paper are needed.

Experiments have been performed which indicate that glass can be incorporated into composite materials that can be used for construction purposes. To dace, glass-polymer composite sewer pipe containing glass separated from ubran waste has been produced and is currently being field tested in two sewage systems. Other potential applications include building blocks, chemical storage tanks, and energy storage devices.

Work has been performed to determine the propertiss of the composite pipe to a degree that they are statistically acceptable with respect to relevant ASTM methods and standards.

The results indicate that, when compared to several ASTM classes of steelreinforced concrete pipe, the use of Glass-Polymer Composite (GPC) eliminates 
the need to use steel and reduces the wall thickness from 30 to $50 \%$. Significant reductions in energy consumption and cost can also be accrued.

Significant Accomplishments in 1977:

1. The mechanical properties of GPC sewer pipe were determined on a scale sufficiently large to make the results statistically defensible with respect to relevant ASTM methods and standards. The results indicate that steel

reinforcement is not required in GPC pipe and, when compared with concrete pipe, the wall thickness can be reduced to 30 to $50 \%$.

2. Ful1-scale pipe sections were installed in two sewage systems.

3. Preliminary calculations were made to determine energy and cost comparisons for the use of GPC pipe as a replacement for vitrified clay. The results indicated that energy savings of up to $16 \%$ can be accrued. Reductions in cost from 11 to $44 \%$ were also indicated.

Principal Activities P1anned for 1978:

1. Specifications for the composition and particle size distribution of the glass needed to produce GPC will be developed.

2. Durability testing of GPC in hot aqueous environments will be started.

3. Energy and cost calculations will be updated on the basis of the results from items 1 and 2 above.

Publications in 1977:

BNL Reports

Steinberg, M., Kukacka, L. E., Fontana, J., Sugama, T., Rayfiel, R., and Galen, B. Development of a Glass Polymer Composite Sewer Pipe from Waste Glass, Progress Report No. 2, OctuberDecember 1976, BNL 50626. 
Steinberg, M., Kukacka, L. E., Fontana, J., Sugama, T., Rayfiel, R., Galen, B. Development of a Glass Polymer Composite Sewer Pipe from Waste Glass, Progress Report No. 3. January-March 1977, BNL 50662.

Steinberg, M., Kukacka, L. E. Fontana, J., Sugama, T., Rayfield, R., Galen, B., and Arnold, G. Development of a Glass Polymer Composite Sewer Pipe from Waste Glass, Progress Report No. 4, April-June 1977, BNL 50690.

Steinberg, M., Kukacka, L. E., Fontana, J., Rayfiel, R., Galen, B., and Arnold, G. Development of a Glass Polymer Sewer Pipe from Waste Glass, Progress Report No. 5, July-September 1977, BNL 50737. 
AN ASSESSMENT OF ENVIRONMENTAL CONTROL TECHNOLOGIES (ECT's)

INVOLVED IN (1) THE FLASH HYDROPYROLYSIS (FHP) OF COAL AND

(2) ATMOSPHERIC CARBON DIOXIDE CONTROL
FY 1977: $\$ 35,000$
Principal Investigators:
M. Steinberg
A. S. Albanese
FY 1978: $\$ 65,000$
Sponsor: Environmental Control Technology (DOE)

\section{Objectives:}

FHP. 1. To identify and quantify the effluents and ECT problems associated with the FHP process.

2. To assess available technology for adequacy and applicability to the FHP process, and identify areas in which new technology is required.

3. To initiate the development of new ECT's as required, on the basis of the above findings.

$\mathrm{CO}_{2} \cdot$ 1. To review methods for removing $\mathrm{CO}_{2}$ from the atmosphere and from energy-related industrial source streams.

2. To assess the values of recovering $\mathrm{CO}_{2}$ for use in producing synthetic fuels and other products.

3. Tn initiate the development of new ECT's, on the basis of the above findings.

\section{Scope:}

The program is comprised of two parts, a major part pertaining to the assessment and control of potential pollutants from Brookhaven National Laboratory's Flash Hydropyrolysis of Coal Process (FHP), and a smaller part dea1ing with an analysis of means of controlling the concentration of atmospheric $\mathrm{CO}_{2}$. Emphasis is on the FHP because of its potential for producing liquid and 
gaseous fuels from coal. The portion of the program pertaining to $\mathrm{CO}_{2}$ draws on information from other organizations concerning global $\mathrm{CO}_{2}$ concentrations and effects. Studies concentrate on an assessment of the technology of environmental control of $\mathrm{CO}_{2}$ from the atmosphere and from energy-related industrial emissions. Concerning the FHP, the approach is to conduct laboratory analyses on samples obtained from BNL's experimental FHP unit currently in operation, and, on the basis of experimental data, prepare conceptual flow diagrams, including mass and energy balances, of full-scale FHP-Chemical and FHP-Refinery complexes. The approach to the $\mathrm{CO}_{2}$ study is to survey the literature and consolidate findings on $\mathrm{CO}_{2}$ emissions and atmospherıc concentration levels. Once this task has been completed, conceptual processing schemes for removing and recovering $\mathrm{CO}_{2}$ from the atmosphere and from industrial source streams will be prepared.

The results of the FHP study will provide an indication of the possible effluents from integrated FHP complexes, provide a basis for establishing environmental guidelines for the FHP and related processes, and identify areas in which new control technologies are required for commercialization of the process. The results of the $\mathrm{CO}_{2}$ study will identify some of the options that are availahle for controlling the level of $\mathrm{CO}_{2}$ in the atmosphere.

Significant Accomplishments. in 1977:

The program was initiated late in the third quarter of 1977 . The major accomplishments and findings during FY 1977 are as follows:

FHP. 1. A conceptual process flow plan and a mass balance for an FHPchemical complex was prepared.

2. The organic phase of the FHP liquid product was quantitatively analyzed for polynuclear aromatic hydrocarbons. 
3. The organic phase of the FHP liquid product was also analyzed for carbon, hydrogen, nitrogen, sulfur and trace elements.

4. Elemental analyses of FHP coal feed (1ignite) and char product were obtained. Volatiles content of coal and char was also determined.

$\mathrm{CO}_{2} \cdot 1$. The historical and anticipated concentration increase of atmospheric $\mathrm{CO}_{2}$ and its possible effects on the environment were investigated.

Principal Activities Planned for 1978:

During FY 1978 it is planned to:

FHP. 1. Prepare an energy balance on a FHP-Chemical complex.

2. Prepare a conceptual flow $\mathrm{pl}$ an and mass and energy balances on a FHP-Refinery complex.

3. Conduct laboratory analyses on samples obtained from BNL's experimental FHP unit to further identify and quantify process effluents.

$\mathrm{CO}_{2}$. 1. Review methods for removing $\mathrm{CO}_{2}$ from the atmosphere and from industrial source streams.

Publications in 1977:

BNL Reports

Steinberg, M., Albanese, A. S. and Dang, V. D. Environmental Control Technology for Atmospheric Carbon Dioxide, Progress Report No. 1, June 20, 1977 to September 30, 1977 BNL 50794.

Steinberg, M. and Albanese, A. S. Environmental Control Technology for the Flash Hydropyrolysis of Coal, Quarterly. Progress Report No. 1, June 20, 1977 to September 30, 1977, BNL 50793. 
CONSERVATION IN THE ETHYLENE POLYMER INDUSTRY: POLYKETONES AND POLYSULFONES
FY 1977: \$0
Principal Investigator: M. Steinberg
FY 1978: $\$ 90,000$
Sponsor: Industrial Energy Conservation (DOE)

\section{Objective:}

The objectives of this program are to develop useful energy-conservation polymers, particularly polyketones and polysulfones, and a process for their manufacture for the plastics. industry.

\section{Scope:}

The program is being performed at BNL in cooperation with an industrial firm (Tenneco). It was shown previously at BNL that $\mathrm{CO}$ can be incorporated with ethylene to produce polyketone polymers and that $\mathrm{SO}_{2}$ can be incorporated with ethylene to produce polysulfone polymers by a high energy radiation technique. These polymers offer a major potential in conserving valuable ethylene raw material and energy for the polyethylene market. $\mathrm{CO}$ and $\mathrm{SO}_{2}$ are low cost and waste raw materials. Estimates indicate a conservation of two billion pounds of ethylene, or $25 \%$ of the overall US market, by substituting $\mathrm{CO}$ and $\mathrm{SO}_{2}$, assuming $50 \%$ penetration of the bulk polyethylene market. The savings amount to more than $\$ 280$ million per year at current market price. The savings in energy alone amount to a substantial 0.1 Quad/yr equivalent and at least 100 billion cubic feet/yr of natural gas. The 1 se of machine radiation may be prefeited because of its possible unique process chemistry, safety, availability, and initial investment. The project focuses on the following three major tasks: (1) establishment of the uniqueness of the radiation process, (2) detcrmination of the processability and marketability of the substitute copolymers, and (3) design, 
construction, and operation of a pilot plant for producing the substituted ethylene copolymers. This project is in support of a program being conducted by Tenneco Inc. under separate agreement with DOE. BNL is to provide technical and supervisory assistance to Tenneco in the form of basic experimental and process information, equipment, and laboratory facilities. Tenneco Inc. is to provide polymer characterization and formulation information, marketing expertise, and scientific and technical assistance at BNL.

\section{Significant Accomplishments in 1977:}

This is a new program to be initiated in FY 1978.

Principal Activities Planned for 1978:

It is planned to (1) establish the unique value of ${ }^{60}$ Co-gamma and electron machine radiation produced copolymer compared to the thermocatalytically produced material, (2) determine the potential processability and marketability of the $\mathrm{CO}$ and $\mathrm{SO}_{2}$ substituted ethylene copolymers, and (3) initiate the design of a pilot plant for production of multipound quantities of the copolymer.

Publications in 1977:

Journal Articles

Steinberg, M. Polyketones and polysulfones for conservation of ethylene polymers. Polymer Engineering and Science 17, No. 5, 335 (1977). 
Programs Proposed for Initiation in FY 1979

In addition to the programs summarized above, the Process Sciences Division has proposed to underake several new programs in FY 1979. These are listed by title below:

Advanced Process for Coal Gasification

High Efficiency Chemical Processes and Power Cycles Involving $\mathrm{CO}_{2}$ Recycle. 